\title{
SPOLUPRÁCE RODINY A ŠKOLY V DOBĚ UZAVŘENÝCH ZÁKLADNÍCH ŠKOL
}

\author{
COOPERATION BETWEEN FAMILY \\ AND SCHOOL DURING THE SHUTDOWN \\ OF PRIMARY SCHOOLS
}

\author{
ROMAN ŠVA ŘÍČEK, JANA STRAKOVÁ, \\ CYRIL BROM, DAVID GREGER, \\ TEREZA HANNEMANN, JIŘÍ LUKAVSKÝ
}

\begin{abstract}
Abstrakt
Clánek na základè kvantitativni a kvalitativni analýzy odpovédí 9810 rodiču zkoumá vnímáni vąélávánív domácim prostředí zpobledu rodiču v době uzavřených základnich škol z dìvodu pandemie COVID-19. Cílem empirického šetreni bylo odpovědèt na otázky, jaké bariéry ve vądèláváni doma v době uzavrèných základnich škol rodiče identifikuji, jaká řěsení by uvitali, ale také jaký je vžtah mezi rodinou a školou v situaci vąèláváni doma. Analyzovaná data pocházeji z vỹzkumu Vz̨déláváni doma, který byl uskutečnèn v dubnu 2020 za podpory České televize. Výsledky výzkumu nkazuji, že existuje zásadni rozdil mezi

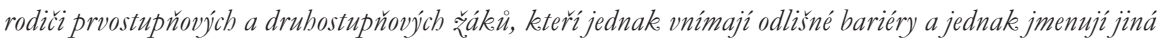
rèseni nastalé situace. V'ỹznam výsledkư tkvi v tom, že nejenom upozornuji na bariéry ve spolupráci mezi rodinou a školou, ale naz̨načuji i možná rèseni problémui, keteré prinesla neočekávaná situace.
\end{abstract}

\section{Klíčová slova}

vaděláváni doma, spolupráce rodiny a školy, zapojení rodiču do vyučování, online výuka, COVID-19

\begin{abstract}
Based on a quantitative and qualitative analysis of the responses of 9,810 parents, this paper examines the perceptions of home education during the COVID-19 lockdown from the parents' point of view. The aim of the empirical survey was to answer questions about what barriers parents identify to home education from shutdown primary schools, what solutions they would welcome, and what the relationship between family and school during the situation of education at home is. The analyzed data come from a survey called Home Education that was conducted in April 2020 with the support of Czech Television. The results of the survey show that there was a fundamental difference between parents of primary and secondary students as they
\end{abstract}


perceived different barriers and also named different solutions to the situation. The significance of the results lies in the fact that they not only point out the barriers to cooperation between the family and the school but also suggest possible solutions to the problems brought about by unexpected situations.

\section{Keywords}

bome education, home-school cooperation, parental involvement in education, online education, COVID-19

\section{Úvod}

Dne 10. března 2020 došlo v České republice k něčemu nevídanému. Žáci základních a stř̌edních škol se vraceli domů ze školy s vědomím, že se kvůli koronavirové pandemii do školy možná dlouho nepodívají. Mnozí z nich byli svými tř́́dními učitelkami a učiteli vybaveni na cestu domů veškerými učebnicemi, pracovními sešity či pomůckami do výtvarné výchovy. Došlo sice k uzavření bran škol, ale výuka se měla nadále odehrávat doma s nápomocí rodičů. Rodiče se tak najednou ocitli ve zcela nové roli, nebot' si bez ohledu na své přání byli nuceni vyzkoušet na vlastní kůži roli pedagoga. Po dlouhé roky existuje v pedagogickém výzkumu velmi důležité téma, kterým je spolupráce mezi učiteli a rodiči jejich žákủ. Mnohé výzkumy však opakovaně přinášejí empirickou evidenci o tom, že navzdory poznání o výhodách rodičovského zapojení (parental involvement) do vzdělávání dětí je to spíše rétorika než skutečnost (Hornby \& Lafaele, 2011). ${ }^{1}$ Najednou se však situace radikálně změnila a všichni rodiče byli chtě nechtě nuceni podílet se na vzdělávání svých dětí. Jak na to rodiče zareagovali? Jak se jim to dařilo zvládat?

Cílem této studie je prozkoumat vnímání vzdělávání doma² z pohledu rodičů a zaměřit se nejenom na to, jaké bariéry ve vzdělávání doma identifikují, jaké řešení by uvítali, ale také jaký je vztah mezi rodinou a školou v situaci vzdělávání doma. Analyzovaná data pocházejí z výzkumu Vzdělávání doma, který byl uskutečněn v dubnu 2020 za podpory České televize.

Přehledové studie ukazují, jak velké množství rozmanitých faktorů způsobuje, že rozdíl mezi rétorikou a realitou $\mathrm{v}$ př́padě rodičovského zapojení je velký. Omezený prostor tohoto textu ani zdaleka neumožňuje jejich podrobný popis, a proto odkazujeme na početné přehledové studie a meta-analýzy (Fan \& Sandoval, 2018; Hornby \& Lafaele, 2011).

2 Pro vzdělávání v domácím prostředí po uzavření škol v rámci karantény používáme označení „vzdělávání doma“/,výuka doma“ nebo „vzdělávání v domácím prostředí“/ „výuka v domácím prostředí. Snažíme se tak vyhnout záměně s ustáleným pojmem „domácí vzdělávání“, který je užíván pro situaci, kdy rodiče celoročně a dobrovolně nahrazují školní docházku domácí výukou (viz Kostelecká, 2017; Machovcová et al., 2020). 


\section{Teoretický rámec}

Rodičovské zapojení neboli rodičovskou angažovanost (Štech, 2004) můžeme jednoduše definovat jako účast rodičů na výchovně vzdělávacích procesech a zkušenostech jejich dětí (Jeynes, 2005). Spolupráce mezi učiteli a rodiči jejich žáků je častým předmětem empirických výzkumů již od konce šedesátých let minulého století (Plowden Report, 1967) a výzkumy opakovaně přinášejí evidenci o tom, že rodičovské zapojení je př́ínosem pro děti všech věkových skupin. Základní teze zní jednoduše: čím větší míra rodičovského zapojení, tím lepší vzdělávací výsledky dětí (Epstein, 1991; Christenson et al., 1992; Jeynes, 2011; Singh et al., 1995). Tento základní axiom však prŕiliš zjednodušuje komplexnost fenoménu rodičovského zapojení. Záleží jen na míre zapojení, nebo bude i jeho forma hrát významnou roli?

Epsteinová (2001) se pokouší na tuto otázku odpovědět s pomocí vymezení šesti typů rodičovského zapojení. Zaprvé se jedná o posilování rodičovských dovedností - školy by měly pomoci rodičům vytvořit podmínky vhodné pro zdravý rozvoj dítěte. Zadruhé jde o komunikaci se školou - školy by měly nejenom informovat o školním vzdělávacím programu, způsobu výuky a pokroku dítěte, ale měly to činit zpo̊sobem srozumitelným pro všechny rodiče. Zatřetí se jedná o dobrovolnické aktivity rodičů ve škole Epsteinová (2001) má na mysli především výpomoc rodičů při organizaci školních oslav, přednášky rodičů nebo čtení ve škole. Začtvrté jde o učení se s dětmi doma, které předpokládá podporu, monitorování, kontrolování či vysvětlování dětem při plnění domácích úkolů. Zapáté jde o přizvání rodičů k rozhodovacím procesům ve škole skrze jejich účast v klubu rodičů či školské radě. A zašesté se jedná o spolupráci v rámci školy jako komunity - rodiče by měli spolupracovat na propojení školy s okolím na komunitní úrovni.

Využití typologie Epsteinové (2001) ve výzkumu přineslo dvě zjištění. Zaprvé, různé formy rodičovského zapojení mohou mít různý dopad na další jevy (Singh et al., 1995). Např́iklad pokud rodiče doma jen kontrolují, zda jejich děti splnily své školní úkoly, podle kvantitativních analýz prakticky neovlivňují školní výsledky svých dětí (Jeynes, 2011). Griffith (1996) dále uvádí, že míra aktivit rodičů ve škole koreluje s výsledky jejich dětí v matematice a čtení, zatímco Galper et al. (1997) uvádějí, že zapojení rodičů má vliv na sebepojetí dětí, či že zapojení rodičů do aktivit ve škole vede k menšímu výskytu problémového jednání (Fantuzzo et al., 2004). Potvrdilo se tak, že některé typy rodičovského zapojení nemusí mít na výsledky žáků ve škole žádný vliv, zatímco jiné jej zásadním způsobem ovlivňovat mohou.

Zadruhé se ve snaze měřit formy rodičovského zapojení objevil metodologicky zajímavý problém: jak měřit rodičovské zapojení, když není vidět? Podoba rodičovského zapojení totiž může být jak veřejná, jako v případě návštěvy rodičů na třídní schůzce, může nabývat skrytých podob, jako v případě 
rodičovské nabídky zakoupení papírů do tiskárny třídní učitelce jejich dítěte, a dokonce se otevřená a skrytá podoba zapojení může prolínat, jak si dále ukážeme na očekávání rodičů směrem ke svým dětem.

Dle výzkumných šetření má největší vliv na vzdělávací výsledky přímá rodičovská pomoc dítěti s učením doma (Fantuzzo et al., 2004). Při ní totiž dochází nejenom k vysvětlování a procvičování učiva, ale rodiče opakovaně dávají svým dětem najevo svá očekávání. Pokud tedy rodiče pomáhají svým dětem a naznačují jim, že by měly ve škole získávat jen ty nejlepší známky, děti vyvinou větší úsilí a díky tomu dosáhnou na lepší hodnocení. Vzdělávací aspirace rodičů potom spolu s přímou rodičovskou pomocí působí jako dva nejsilnější faktory ovlivňující dosažené školní výsledky (Fan \& Chen, 2001; Jeynes, 2011), i když jejich působení je zčásti skryté.

Problematické navíc zůstává to, jak měříme vzdělávací výsledky. Fan a Chen (2001) ve své kvantitativní meta-analýze 25 velkých studií o vlivu rodičovského zapojení na vzdělávací výsledky žáků upozornili, že nejsilnějším prvkem ovlivňujícím žákovské výsledky jsou rodičovské aspirace ohledně akademických výsledků jejich dětí. Ruku v ruce s tímto závěrem je však zjištění, že pokud vzdělávací výsledky měříme za všechny předměty (tedy průměr ze všech předmětů), pak je tento vztah silnější, než když výsledky měříme ve vybraném předmětu (např. matematice nebo čtení).

Typologie rodičovského zapojení Epsteinové (2001) vychází z přesvědčení, že rodina, škola a komunita jsou tři vzájemně související sféry, jejichž propojení je důležité pro ideální rozvoj dítěte. V českých školách zcela výjimečně najdeme všechny typy rodičovského zapojení dle Epsteinové (2001). Nejčastějšími typy zapojení jsou komunikace rodiny a školy a učení se s dětmi doma, naproti tomu posilování rodičovských dovedností dnes nenalezneme takřka nikde a přizvání rodičů $\mathrm{k}$ rozhodovacím procesům ve škole se zpravidla týká jen několika málo jednotek rodičů na dané škole. Ho a Kwong (2013) proto přicházejí s jednodušším členěním rodičovského zapojení oproti Epsteinové. Prvním typem je interakce rodičů a dítěte v domácnosti (home-based involvement), jejímž cílem je přímo zlepšit učení dítěte a jeho výkon ve škole. Druhým typem je zapojení rodičů do aktivit školy (school-based involvement) a třetím typem je zapojení rodičů do správy školy (school governance), kdy se rodiče spolupodílejí na rozhodovacím procesu školy.

Je očekávatelné a opakovaně empiricky potvrzené, že mezi mírou zapojení rodičů a jejich socioekonomickým statusem existuje silná souvislost (Bracey, 1996; Katrňák, 2004). Více angažovaní rodiče jsou zároveň rodiče, kteří mají vyšší socioekonomické zázemí. Šed’ová (2009) ve svém kvalitativním výzkumu vztahů rodičů a učitelek na prvním stupni základní školy přinesla zjištění, že učitelky vykazují velké množství úhybných interakčních rituálů (nap̌r. se snaží vyhnout kontrole ze strany rodičů, snahám rodičů o zvýhodňování svých dětí, odmítají dobrovolnické rodičovské aktivity), 
a to zejména vưči rodičům s vyšším socioekonomickým statusem. Pokud platí originální výzkumné zjištění Šed’ové (2009), tak se sice škola snaží některým skupinám rodičů bránit v prosazování jejich zapojení do procesů školy, ale nemůže zasahovat do domácí přípravy rodičů s dětmi. Rodičům s vyšším socioekonomickým statusem tedy stále zůstává přímá rodičovská pomoc dítěti s učením doma, která je považována za nejsilnější typ rodičovského zapojení s ohledem na pozdější vzdělávací výsledky dítěte (viz Fantuzzo et al., 2004). To vlastně zpětně vysvětluje, proč se přímé učení s dětmi doma jeví jako efektivní rodičovská strategie a proč je důležitější než ,jen“ výše socioekonomického statusu rodičů.

Škola tudíž může do jisté míry regulovat rodičovské zapojení, a proto nelze jednoznačně tvrdit, že socioekonomický status determinuje míru rodičovského zapojení. Rodiče netvoří homogenní skupinu (Munn, 1993), protože disponují odlišným př́stupem ke škole jako takové, k učitelům či důležitosti učení, což může být dáno nejen socioekonomickým, ale i kulturním a etnickým zázemím. Rodiče nadto svůj přístup neustále přetvářejí ve vzájemné interakci se školou. Jaké př́istupy ke škole tedy u rodičů můžeme nalézt?

Na rodiče tak můžeme nahlížet jako na qákazniky či klienty školy. Učitelé jsou rodiči považováni za odborníky na vzdělávání a jejich úkolem je dobře se starat o své klienty (žáky) a informovat rodiče o učení jejich dětí ve škole. Rodiče jsou spíše těmi, kteří si mají obstarat finanční zdroje pro chod domácnosti, kteří ví, jaké služby mají po škole chtít, a jejich hlavním úkolem je vybrat správně školu pro své dítě. Svobodný výběr školy ze široké nabídky vzdělávacího trhu je pro rodiče hlavním mechanismem zasahujícím do kvality školy (Bridges, 1994). Vedle práva na svobodný výběr je zákaznický přístup charakteristický právem na informace o pokroku dítěte ve škole ${ }^{3}$ a právem na kvalitní výuku. Reprezentativní výzkum Rabušicové et al. (2004) ukázal, že nejrozšířenější rolí ve vztahu ke škole je právě role zákaznická. S rozšířením zákaznického pojetí zřejmě souvisí i prokázaný značný pokles rodičovské angažovanosti v pomoci s učením a kontrolou úkolů mezi lety 1991 a 2002 (viz Rendl \& Škaloudová, 2004). Rodiče mohou mít pocit, že vše je na bedrech školy, zatímco učitelé mohou na druhé straně cítit velký tlak ze strany rodičů, který však není doprovázen podporou směrem k jejich dětem. Výsledkem může být absence zapojení rodičů zejména z marginalizovaných skupin obyvatelstva, nejen kvůli ekonomickým důvodům, ale zejména kvůli přesvědčení, že vzdělávání je úkolem učitelů, nikoliv rodičů (Auerbach, 2007).

3 Empirická evidence opakovaně ukazuje, že by si rodiče přáli mít o pokroku svých dětí více informací (viz Štech, 2004). V této souvislosti je důležité zmínit, že děti své rozhovory s rodiči o průběhu školní docházky regulují (Smetáčková, 2012). 
$\mathrm{Na}$ rodiče se můžeme dále dívat jako na partnery školy. Jedna z prvních zmínek o partnerství mezi rodinou a školou (Plowden Report, 1967) vyzdvihuje partnerství jako potřebný koncept pro vzdělávání a výchovu dětí. Podle Bastianiho (1993) staví partnerství na sdílených cílech, vyjednávání, vzájemném respektu a dialogu mezi rodinou a školou. Obě strany mají rovnoprávný vztah a respektují roli obou stran v rozvoji dítěte. Termín partnerství natolik kontaminoval všechny úrovně vzdělávací politiky, že je obtížné odlišit idealizovanou realitu od skutečného stavu. Vágně definovaný termín partnerství však může mít různé významy pro různé skupiny rodičů (Hegarty, 1993) a může spíše zakrývat odlišný stav věci. Ve výzkumu vedeném Rabušicovou (2004) byla partnerská role postavená na rovnoprávném vztahu obou stran identifikována jen zrrídka. ${ }^{4}$ Spíše než rétoricky chválené partnerství vidíme v praxi přístup „normální je nekomunikovat“ - pokud je vše ve škole v pořádku, není třeba, aby rodiče se školou vedli partnerský rozhovor (viz Štech, 2004).

Vychází najevo, že centrálním elementem komunikace rodiny a školy je již zmíněné prospívání či neprospívání dítěte, na které mohou mít všichni aktéři diametrálně odlišný náhled. Štech a Viktorová (2001) vytvořili tři různá pojetí rodičovského vztahu ke škole založeného na zkušenosti s prospěchem dítěte. Rezignované (alternativní) pojetí zastávají rodiče, jejichž dětem se ve škole nedaří, a oni si proto vytvářejí únikovou strategii skrze rezignaci na požadavky školy. Rezignují jak na učení se s dětmi doma, tak na komunikaci se školou. Komplementární pojetí můžeme vidět u rodičů, kteří upevňují moc učitele a školy. Tito rodiče pocit'ují zodpovědnost za to, aby jejich dítě mělo splněné úkoly, procvičují s ním látku a spíše prodlužují působení učitele. Nahrazujicí (kritické) pojetí vidíme u rodičů, kteří školu jednak viní z nedostatečného plnění výchovně-vzdělávacích úkolů, a jednak se domnívají, že svým přičiněním mohou tyto nedostatky skrze učení se s dětmi doma napravit.

Je pravděpodobné, že učitelé budou více komunikovat s rodiči o očekávání směrem ke známkám či chování právě u těch rodičů, které můžeme vřadit pod komplementární pojetí. Rodiče pak konzistentně s tím mohou tato očekávání u svých dětí doma značně posilovat (Kim et al., 2013).

Jaké jsou oproti tomu důvody rodičovského nezapojování se? Hornby a Lafaelová (2011) se pokusili na základě meta-analýzy shrnout všechny bariéry do modelu skládajícího se ze čtyř hlavních kategorií: 1) společenské faktory ovlivňující jak rodinu, tak také školu (politické, ekonomické, historické a demografické faktory), 2) faktory ovlivňující vztah rodiče a učitele (odlišné cíle, postoje a jazyk), 3) faktory na straně rodičů a rodiny (přesvědčení rodičů o zapojení, vnímané přizvání k zapojení, životní podmínky, sociální třída,

Na rodiče bez zájmu o školu, na rodiče nekomunikující či naopak na rodiče přehnaně aktivní (viz Šed’ová, 2004) lze pohlížet jako na problém. 
etnikum, pohlaví) a 4) faktory na straně dítěte (věk, specifické poruchy učení, problémy s chováním). S ohledem na téma článku a omezený rozsah se budeme dále věnovat faktorům na straně dětí, jelikož souvisejí s naším šetřením.

Věk dítěte významně koreluje s mírou rodičovského zapojení - zatímco v mateřských školách je míra zapojení mnohem větší než na prvním stupni, na druhém stupni ZŠ je potom mnohem nižší než na prvním stupni (Seginer, 2006). To může být zaprvé dáno tím, že se s postupujícími ročníky mohou cítit rodiče méně kompetentní vypomáhat dětem s domácími úkoly, protože probírané látce nerozumí (Hill \& Tyson, 2009). Druhé vysvětlení se opírá o psychologický proces dospívání, v průběhu kterého se děti stávají samostatnější a chtějí být nezávislými na svých rodičích, a to i při domácích úkolech (Hornby \& Lafaele, 2011). V rozporu s tímto tvrzením stojí zjištění z výzkumu bezmála devíti set čtrnáctiletých amerických teenagerů (Deslandes \& Cloutier, 2002). I když čtrnáctiletí nechtějí, aby se jejich rodiče šli podívat do vyučování nebo aby se účastnili školního výletu, takřka 80 \% dospívajících uvádí, že doma svým rodičům rádi ukazují, co se naučili ve škole, nebo že se jich rádi ptají na rady ohledně domácích úkolů. Apriorní snaha dětí odmítat jakékoliv zapojení rodičů není vidět, nejspíše jsme svědky proměny formy zapojení (např́iklad na prvním stupni by děti ocenily právě zmíněnou účast rodičů na školních výletech či přítomnost svých rodičů ve vyučování, zatímco na druhém stupni nikoliv).

V seznamu bariér bychom mohli pokračovat, ale podstatné je zdůraznit, že bariéry různou měrou ovlivňují různé typy rodičovského zapojení (viz Epstein, 2001). Platí také, že různé bariéry působí různým způsobem na odlišné skupiny obyvatel. Rodiče přistěhovalci sice mohou být nadprůměrně časově vytíženi svou prací, což se projevuje nadprůměrně nízkou mírou jejich zapojení do domácí př́pravy svých dětí. Ovšem právě tito rodiče mají vysoká očekávání směrem ke svým dětem a důrazně je nutí, aby je naplnily (Turney \& Kao, 2009).

Konceptualizace rodičovského zapojení s využitím prístupu rodičů ke škole přináší zajímavé výsledky, nebot’ $v$ daleko jemnějším rozlišení dokládá vliv jednotlivých aspektů na jiné. Rodiče s rezignovaným pojetím tedy nutně nemusí být rodiče s nízkým socioekonomickým zázemím, ale rodiče výborně prospívajících žáků, kteří od školy dostali jasnou zprávu, že se nemají angažovat ${ }^{5}$. Jak na základě kvalitativního šetření nezapojených rodičů tvrdí Williamsová a Sánchezová (2012), může rovněž jít o rodiče, jejichž prvotní snaha komunikovat s učitelem a zapojit se do aktivit školy nevedla ke kýženému efektu, a proto se rodiče rozhodují neangažovat se.

Pokud jsou rodiče přesvědčeni, že si škola nepřeje, aby se zapojovali, ve výsledku se prakticky nezapojují (Williams \& Sánchez, 2012). 


\section{Metodologie výzkumu}

\section{Anketa V̌délávání doma}

Cíl výzkumu Vzdělávání doma a použité metody se odvinuly od okolností, za kterých výzkum probíhal. Poněkud znenadání a bez př́ípravy došlo k časově neurčené uzavírce škol a děti se vzdělávaly pouze skrze prvky distančního vzdělávání. Učitelé i rodiče se snažili se s novou situací vyrovnat, přičemž o tom, jak se jim to dař́, byly k dispozici pouze útržkovité informace ${ }^{6}$. Cílem výzkumu, který bychom správně měli označit spíše jako anketu ${ }^{7}$, bylo se rychle a rámcově poučit o tom, jak rodiče vzdělávání doma zvládají, a $\mathrm{v}$ př́ípadě nálezu zásadnějších obtíží poskytnout zpětnou vazbu školám, př́padně subjektům, které ke vzdělávání doma prrispívaly dodávkou vlastních vzdělávacích programů. V souladu s tímto cílem autoři neaspirovali na získání reprezentativního výběru respondentů ${ }^{8}$ ale snažili se rychle oslovit co největší (a nejširšši) publikum.

Jako výzkumný nástroj byl zvolen krátký elektronický dotazník, který byl masivně inzerován v České televizi a na sociálních sítích. Dotazník byl určen rodičům a cílen na vzdělávání vybraného dítěte $\mathrm{v}$ povinném vzdělávání Prostřednictvím uzavřených otázek se tázal na časovou náročnost současného vzdělávání v domácím prostředí ve srovnání s běžným režimem, na míru asistence rodičů při různých typech domácích činností, na vnímanou užitečnost zadávaných úkolů a jejich přiměřenost, na subjektivní hodnocení míry, v jaké se vzdělávání v domácím prostředí rodině daří. Zjišt’oval rovněž kontext, ve kterém vzdělávání probíhá: pohlaví dítěte a navštěvovaný ročník,

${ }^{6} \quad$ V době zahájení sběru dat nebyly $\mathrm{k}$ dispozici žádné výzkumné poznatky. V průběhu realizace sběru dat byly zveřejněny výsledky výzkumu PAQ research Život během pandemie, který se zabýval rovněž otázkou vzdělávání v domácím prostř̌edí (Prokop et al., 2020). Výzkum byl realizován na Českém národním panelu na výběru 2639 respondentů, z čehož 536 respondentů vychovávalo děti navštěvující ZŠ a SŠ, tedy odpovídalo na otázky týkající se distančního vzdělávání. Výběr byl reprezentativní z hlediska složení populace $18+$, ovšem zahrnoval pouze respondenty s online připojením. Výzkum zjišt’oval formy zadávání úkolů, četnost komunikace školy s rodinou, zatížení dítěte a rodičů a celkovou spokojenost s prací školy.

Anketa je charakteristická samovýběrem, což byl i případ našeho šetření, a nelze z ní tudíž provádět zobecnění. Při potřebě rychlé orientace v novém tématu je však nezastupitelná (viz např̀. Dvořák, n. d.).

8 Reprezentativní výzkum nepřipadal v úvahu i vzhledem $\mathrm{k}$ omezením v mezilidském kontaktu, která vylučovala výzkum v domácnostech. Sběr dat bylo možné uskutečnit pouze prostřednictvím informačních a komunikačních technologií, což okruh respondentů nutně zužuje.

9 Rodiče byli vyzváni, aby v prrípadě, že mají v rodině více dětí v povinném vzdělávání, vypovídali o tom, o jehož školní práci mají nejvíce informací. 
nejvyšší dosažené vzdělání rodičů, respektive opatrovníků, počet členů domácnosti, velikost obce, ve které rodina žije, a míru dopadu opatření spojených s epidemií na rodinu. Dotazník obsahoval rovněž dvě otevřené otázky, které se týkaly identifikace problémů a potenciálních cest $\mathrm{k}$ jejich odstranění.

Průzkum proběhl mezi 1. a 9. dubnem 2020. Dotazník vyplnilo 9810 respondentů. I přes vysoký počet respondentů jsme si vědomi toho, že výpovědní hodnota ankety je velmi omezená, nebot' dotazník vyplnila pouze určitá skupina rodičů. Jednalo se o rodiče, kteří se o šetření dozvěděli a byli ochotni a schopni elektronický dotazník vyplnit. Domníváme se, že z jejich výpovědi můžeme usuzovat na to, jak krátce po zavedení karanténních opatření vnímali vzdělávání doma rodiče, kteří mají zájem o vzdělávání svých dětí, snaží se dostát požadavkům školy a rutinně pracují s internetem.

Vycházíme z toho, že se jedná o výpověd' charakterizující situaci značné části rodin v ČR. Při interpretaci získaných údajů musíme však mít na paměti, že existuje i další významná skupina rodičủ, kteří nepracují s internetem a/nebo svým dětem se vzděláváním nemohou, někdy ani nechtějí pomoci. Náš výzkum neposkytuje žádnou informaci o tom, jak velký podíl žáků realizuje vzdělávání v domácím prostředí v takových rodinách ani jakým problémům tyto rodiny čelí.

\section{Výzkumný problém a výzkumné otázky}

Deskriptivní analýzy získaných kvantitativních dat (Brom et al., 2020a, 2020b) poskytly informace o tom, kolik času tráví žáci aktuálně školní prací, jaké pomoci se jim dostává od rodičů a zda jsou úkoly, které dostávají ze školy, z pohledu rodičů príměřené. Výsledky napověděly, že u respondentů výzkumu nezpůsobuje vzdělávání doma žádné větší problémy. Většina rodičů vyjádřila pocit, že vzdělávání dítěte $\mathrm{v}$ domácím prostředí zvládají a že zadávané úkoly hodnotí jako spíše užitečné. Objem úkolů hodnotili rodiče jako vyšší nebo přiměřený, pouze malá část rodičů vyjádřila názor, že děti jsou školou vytěžovány nedostatečně.

Cílem této stati je podívat se podrobněji na informace, které rodiče poskytli v otevřených otázkách. Domníváme se, že tyto výpovědi mohou zprostředkovat detailnějěsí vhled do toho, jak rodiče o vzdělávání svých dětí přemýšlejí, co oceňují na práci pedagogů a co v ní naopak postrádají.

\section{Výzkumné otázky:}

1. Je možno mezi rodiči vysledovat skupiny s podobným př́stupem? Co je pro tyto skupiny charakteristické?

2. Jaké bariéry ve vzdělávání doma vnímají rodiče?

3. Jaká řešení ke zlepšení situace rodiče navrhují?

4. Jakou úlohu by měly podle názoru rodičů hrát ve vzdělávání jejich dětí informační technologie? 
5. Jak vypovídá rodičovské hodnocení vzdělávání v domácím prostředí o vztahu rodičů ke škole a učitelům svých dětí?

\section{Datový soubor}

Datový soubor obsahoval výpovědi o 9810 vzdělávaných dětech. Obsahoval numerické a ordinální proměnné charakterizující pohled rodičů na vzdělávání doma ve srovnání s běžným školním rě̌imem (doba strávená školní prací, míra pomoci rodičů, odhad doby potřebné pro splnění všech povinností, užitečnost úkolů), míru zapojení rodičů do dílčích aktivit (vysvětlování úkolů, plnění úkolů, vysvětlování učiva, kontrola) a subjektivní hodnocení zvládání vzdělávání v domácím prostředí. Kromě toho obsahoval soubor i některé proměnné charakterizující dítě (pohlaví, ročník) a rodinu respondenta (vzdělání rodičů, obec, ve které rodina žije, počet členů domácnosti, dopad opatření spojených s karanténou na rodinu). Kromě toho obsahoval volné odpovědi na otázky: Co vám nejvíce komplikuje vzdělávání dítěte doma? a Co by vám při vzdělávání doma nejvíce pomohlo? Délka odpovědí se pohybovala od 3 do 4500 znaků bez mezer, průměrná délka odpovědi byla 70 znaků bez mezer, medián 38 znaků.

\section{Etika výzkumu}

Dotazník po respondentech nevyžadoval vyplnění žádných osobních údajů, a proto jsme nemuseli provádět anonymizaci dat ani žádat o schválení etickými komisemi zapojených institucí. Tento postup nás sice připravil o možnost kontaktovat respondenty pro bližší vysvětlení některých odpovědí či spojit data s jednotlivými kraji republiky, ale rozhodli jsme se tak především proto, abychom data získali rychle. Schvalování etickými komisemi zapojených institucí by totiž mohlo značně oddálit sběr dat.

\section{Metody analýzy dat}

\section{Tematická obsahová analýza otevřených otázek}

Prvním krokem analýzy otevřených otázek byla tematická obsahová analýza (Carley, 1993; Bowen, 2009), jejímž cílem bylo induktivně zjistit, jaká témata se v odpovědích vyskytují, zda je možné jednotlivá témata uspořádat do větších tematických celků (kategorií) a v neposlední míře zjistit četnost výskytu konkrétních kategorií. V prvním kole tematické obsahové analýzy prošli samostatně první dva autoři textu všechny odpovědi na obě otevřené otázky a každý vytvořil seznam opakujících se kódů (každý seznam obsahoval přibližně 70 kódů). V druhém kole došlo k vytvoření kratšího seznamu deseti kategorií, které byly po dohodě mezi oběma autory redukovány na šest hlavních: 1 - účast učitele při vzdělávání dítěte, 2 - množství úkolů, 3 - pedagogické dovednosti rodiče, 4 - časová tíseň, 5 - vybavení domác- 
nosti, 6 - specifika vzdělávaného dítěte. Ve třetím kole byl vytvořen manuál pro kodéry, kde bylo všech šest kódů pečlivě vysvětleno a byly u každého z nich uvedeny nejčastější př́iklady výskytů. Ve čtvrtém kole provedlo dle vytvořeného manuálu pět kodérů manuální číselné kódování všech odpovědí na otevřené otázky (v př́ípadě první otevřené otázky se jednalo o 6476 odpovědí, u druhé otázky o 7153 odpovědí). Použití strojového kódování či automatického kódování na základě počtu výskytů kódů nebylo možné, protože některé odpovědi na otevřené otázky neobsahovaly českou diakritiku. V pátém kole první dva autoři textu provedli kontrolu kódování a připravili datovou matici pro shlukovou analýzu.

\section{Shluková analýza}

$\mathrm{S}$ cílem rozdělit respondenty do skupin se společnými charakteristikami jsme na datový soubor aplikovali shlukovou analýzu. Výpočty byly provedeny v SPSS 21. Kvůli chybějícím odpovědím na otevřené otázky ( $27 \%$, respektive $34 \%$ ) a některým dalším chybějícím odpovědím vstoupilo do shlukové analýzy pouze 5482 prrípadů. Popisné charakteristiky souboru uvádíme v př́loze.

Vzhledem k vysokému počtu respondentů a skutečnosti, že do analýzy vstupovaly spojité i ordinální proměnné, jsme volili proceduru Two-Step Cluster analysis v defaultním nastavení. Pro interpretaci jsme zvolili řešení ${ }^{10}$, do něhož vstupovaly následující proměnné:

- první stupeň: dítě navštěvuje 1.-5. ročník povinného vzdělávání (1: ano, 0: ne)

- asistence rodiče: odpověd’ na otázku: Kolik procent z celkového času, které dítè vènuje studiu, mu pomáhám já nebo někedo jiný z rodiny? (1: málo - méně než $40 \%$ času, 2: středně - 40-60\% času, 3: hodně - více než $60 \%$ času)

- vnímaná užitečnost úkolů: reakce na tvrzení: Školní práce, keteré se nyní mé ditè vènuje (plnèni úkolü, online setkáváni s učitelem...), mi celkově pripadá (1: velmi užitečná, 2: spíše užitečná, 3: spíše neužitečná, 4: velmi neužitečná)

10 Jednalo se o řešení přijatelné z hlediska orientačního ukazatele kvality (Silhouette measure $=0,4$ ) a zároveň takové, které rozlišovalo v proměnných, jež nám připadaly důležité z hlediska interpretace. Ve shlukové analýze jsme pracovali rovněž s proměnnými charakterizujícími počet dětí v rodině, vzdělání rodičů, velikost obce, míru pomoci rodiče s různými typy úloh, dopad opatření zavedených v souvislosti s koronavirem na respondenta a subjektivní míru zvládání výuky v domácím prostředí. Tyto proměnné však mezi respondenty téměř vůbec nerozlišovaly. Zároveň se nám nepodařilo nalézt žádné rozumné řešení, které by rozlišilo nějaké podskupiny v rámci dvou identifikovaných hlavních skupin. 
- čas strávený učením: odpověd’ na otázku: Kolik času se nyni uči mé díté v pracounim dni školni látku? (1: skoro žádný, 2: půl hodiny až hodinu, 3: hodinu, 4: 2 hodiny, 5: 3 hodiny, 6: 4 hodiny, 7: 5 hodin, 8: 6 hodin, 9: 7 hodin a více)

- Za stěžejní z hlediska naší analýzy jsme považovali odpovědi na otevřené otázky č. 12 a 13. Odpovědi na tyto otázky jsme s pomocí tematické obsahové analýzy (viz výše) rozdělili do šesti hlavních skupin (1: účast učitele při vzdělávání dítěte, 2: množství úkolů, 3: pedagogické dovednosti rodiče, 4: časová tíseň, 5: vybavení domácnosti, 6: specifika vzdělávaného dítěte). Těchto šest hlavních kategorií bylo v další analýze rozčleněno na další jednotky.

\section{Kvalitativní obsahová analýza otevřených otázek}

Druhým krokem analýzy otevřených otázek byla kvalitativní obsahová analýza odpovědí na otevřené otázky (Mayring, 2000; Roberts, 1989). Na základě tematické analýzy byly odpovědi rozřazené do šesti základních kategorií, které byly nyní nově předmětem detailní kvalitativní analýzy. Cílem bylo zaprvé vysvětlit jednotlivé kategorie a popsat, proč respondenti odpovídali daným způsobem při svém podrobném vysvětlení (např. Proč by rodiče rádi rozšíríili online výuku? Jak vnímají online výuku?). Zadruhé jsme chtěli postupně odpovědět na čtyři výzkumné otázky (VO 2, 3, 4, 5). Pomocí otevřeného induktivního kódování (Konopásek, 2005; Švaříček et al., 2007) jsme postupně interpretovali pouze ty odpovědi respondentů, které podrobné vysvětlení obsahovaly a krátké či nedokončené odpovědi do analýzy nevstupovaly.

\section{Výsledky výzkumu}

Z výzkumu Vzdělávání doma vyplynulo, že rodiče jsou s průběhem vyučování v domácím prostředí spíše spokojeni a mají pocit, že ho jejich rodina v zásadě zvládá. Odpovědi na otevřené otázky však ukazují, že rodiče narážejí na celou řadu bariér a vidí řadu řešení, jak vzdělávání v domácnostech vylepšit. Kombinace dat kvalitativní a kvantitativní povahy nám umožňuje vhled do situace z pohledu rodičů.

\section{Dvě skupiny rodič̃: proni a drubý stupeň}

V tabulce 1 uvádíme výsledky shlukové analýzy. Z tabulky je zřejmé, že jako hlavní kritérium při tř́dění se uplatnil ročník, který dítě navštěvuje (první vs. druhý stupeň). Tomuto rozdělení odpovídá i počet klastrů a hodnoty dalších proměnných. 
Tabulka 1

Výsledky shlukové analýzy

\begin{tabular}{|c|c|c|c|c|}
\hline & \multicolumn{2}{|c|}{ klastr $2(\mathrm{~N}=3649)$} & \multicolumn{2}{|c|}{ klastr $1(\mathrm{~N}=1833)$} \\
\hline & průměr & SD & průměr & $\mathrm{SD}$ \\
\hline první stupeň & 1,00 & 0,00 & 0,05 & 0,23 \\
\hline asistence rodiče & 2,39 & 0,75 & 1,80 & 0,80 \\
\hline vnímaná neužitečnost úkolů & 1,94 & 0,73 & 2,43 & 0,79 \\
\hline čas strávený učením & 5,06 & 1,29 & 6,07 & 1,65 \\
\hline Co mi komplikuje život... & \multicolumn{2}{|c|}{$\%$} & \multicolumn{2}{|c|}{$\%$} \\
\hline učitel neposkytuje vysvětlení látky & 7,7 & & 19,7 & \\
\hline úkolů je prŕiliš mnoho & 3,6 & & 14,9 & \\
\hline nemám pedagogické dovednosti & 12,5 & & 15,4 & \\
\hline málo času & 37,8 & & 25,8 & \\
\hline mnoho domácích povinností & 25,0 & & 16,8 & \\
\hline dítě s malým zájmem o výuku & 13,5 & & 7,3 & \\
\hline Co by mi pomohlo... & \multicolumn{2}{|c|}{$\%$} & \multicolumn{2}{|c|}{$\%$} \\
\hline více učitele & 49,3 & & 54,6 & \\
\hline méně úkolů & 9,8 & & 20,7 & \\
\hline pedagogické dovednosti & 11,2 & & 10,0 & \\
\hline více času & 12,3 & & 6,3 & \\
\hline méně domácích povinností & 13,2 & & 7,0 & \\
\hline dítě s větším zájmem o výuku & 4,2 & & 1,4 & \\
\hline
\end{tabular}

Nejprve popíšeme oba klastry a posléze se budeme věnovat detailnímu popisu jednotlivých proměnných, které vysvětlujeme s pomocí analýzy odpovědí na otevřené otázky.

\section{Rodiče prvostupňových žáků (klastr 1)}

V prvním klastru jsou rodiče žáků prvního stupně, kteří tráví pomocí svým dětem $40-60 \%$ z celkové doby studia, kterou jí věnuje jejich dítě. Užitečnost zadaných úkolů vnímají lépe než rodiče žáků druhého stupně, mezi velmi užitečné a spíše užitečné. Jejich děti tráví školní prací o hodinu méně času než druhostupňoví žáci, v průměru 3 hodiny denně.

Nejvíce jim situaci komplikuje málo času na výuku $(37,8$ \%) a špatné vybavení domácnosti z hlediska informačních technologií (25\%). Méně často se pak objevuje absence pedagogických dovedností a znalostí (12,5\%), špatný př́stup dítěte $(13,5 \%)$, absence vysvětlení úkolů učitelem $(7,7 \%)$ a velké množství úkolů (3,6\%). 
Stejně jako rodiče druhostupňových žáků by nejvíce uvítali online výuku (49,3\%). Dále by jim pomohlo lepší vybavení domácnosti (13,2\%), více času $(12,3 \%)$, získání pedagogických dovedností (11,2\%), méně úkolů $(9,8 \%)$ a dítě s lepším přístupem ke školním povinnostem (4,2\%).

\section{Rodiče druhostupňových žáků (klastr 2)}

Druhý klastr spojil rodiče žáků druhého stupně, protože vykazují tyto společné charakteristiky. Rodiče pomáhají svým dětem méně než ve $40 \%$ času z celkové doby studia, kterou jí věnuje jejich dítě. Užitečnost zadaných úkolů vnímají hưře než rodiče žáků prvního stupně, mezi spíše užitečné a spíše neužitečné. Udávají, že jejich děti tráví školní prací v průměru 4 hodiny, což je více než prvostupňoví žáci.

Nejvíce jim situaci komplikuje nedostatek času na výuku (25,8 \%), špatné vybavení domácnosti z hlediska technického vybavení potřebného na výuku (16,8 \%), absence vysvětlení úkolů učitelem (19,7\%) a absence pedagogických dovedností a znalostí (15,4\%). Teprve na předposledním místě je velké množství úkolů $(14,9 \%)$ a nejméně přístup samotného dítěte $(7,3 \%)$.

Nejvíce by naopak uvítali online výuku (54,6 \%) a méně úkolů (20,7 \%). S menší četností se pak objevuje získání pedagogických dovedností (10\%), lepší počítačové vybavení domácnosti (7\%), více času $(6,3 \%)$ a lepší prrístup dítěte $(1,4 \%)$.

Hlavní zjištění ze shlukové analýzy jsou tato: Zhruba polovina rodičů prvního i druhého stupně by si přála online výuku a více než třetina se shodne na tom, že největší komplikací je čas, který mohou věnovat výuce. Dále se však zjištění v obou skupinách liší.

Rodiče prvostupňových dětí jsou nejvíce zatíženi péčí o dítě a více postrádají v domácnosti technické vybavení potřebné pro výuku. Při společném učení průměrně hodinu a půl denně zjišt'ují, že jejich dítě si ve škole neosvojilo studijní návyky. Zadané úkoly považují za užitečné a přáli by si mít více času a pedagogických dovedností, aby zvládli lépe společné učení.

Rodiče druhostupňových dětí jsou nejvíce zatíženi náročností kurikula druhého stupně, a proto jim společné dvouhodinové učení denně nejvíce komplikuje absence vysvětlení látky učiteli. Úkoly jim nepřipadají př́liš užitečné, raději by si jich přáli méně a více by chtěli ovládnout pedagogické dovednosti.

\section{Bariéry ve vzdéláváni doma}

Podrobnější pohled na odpovědi rodičů umožňuje blíže se seznámit s tím, co se skrývá pod kódy, se kterými jsme pracovali ve shlukové analýze, a tedy porozumět komplikacím, kterým rodiče při vzdělávání doma čelí. Níže analyzujeme nejčastěji se vyskytující okruhy problémů. 


\section{Nedostatečné vybavení domácností}

Nejčastější problémy, kterým rodiče čelí, souvisejí s nedostatkem času a s omezenými zdroji, které mají v domácnosti k vyučování $\mathrm{k}$ dispozici. Řada rodičů chodí do zaměstnání nebo musí odvést z domova stejné množství práce jako obvykle, $\mathrm{k}$ tomu musí nakupovat a vařit. $\mathrm{V}$ rodině je více dětí, tedy je třeba se učit s několika školáky nebo se starat o mladší dítě, aby nerušilo starší dítě při práci. Rodičům však často nemohou vypomoci prarodiče, jak by bylo možné $\mathrm{v}$ př́ípadě jiného onemocnění.

Hlavním nedostatkovým zbožím se stává čas, jak popisuje ve výpovědi matka žákyně 7. třídy: ,... pracovat v práci 8 hodin, večer v 18 hod. príjít domü, dělat vě̌eri a po 19. hodinè vysvètlovat ứeni a dělat úkoly a už ve 21 hod. jit spát, protože do práce vstávám ve 4 hodiny. "Matka žákyně shrnuje, že se současní rodiče často ocitají v trojroli: chodí do zaměstnání, starají se o domácnost a pomáhají se vzděláváním svých dětí. Skloubit tyto tři role není pro rodiče snadné a míru zátěže přirovnávají $\mathrm{k}$ tomu, jako by $\mathrm{k}$ práci na plný úvazek z domova dostali další poloviční úvazek pedagoga.

Druhým problémem je absentující technické vybavení pro vzdělávání doma. V rodině často není dostatek počítačů, a tak nastávají situace, že na jednom rodinném počítači musí rodič vykonávat home-office a zároveň by na něm měla probíhat výuka jednoho i více dětí. Rodiče si pak kladou otázku, zda je nutné, aby dítě vypracovávalo projekty na počítači nebo tam vyhledávalo informace. Myslí si snad učitelé, že se dítě nudí, a proto mu zadávají další úkoly? ptají se někdy.

Rodiny nemají tiskárny, skenery, nemají potřebné programy (např. program na prezentace), a často si stěžují na nestabilní internetové připojení. V některých rodinách počítač chybí a komunikace se školou probíhá prostřednictvím mobilního telefonu. Situaci komplikuje skutečnost, že v některých školách používají různí učitelé různé platformy, a rodiče se tedy musí učit pracovat $\mathrm{v}$ různých prostředích. Rodiče si stěžují na nedostatek učebnic i pomůcek pro další školní činnosti (výtvarná výchova). Ani dispozice bytů často není taková, aby poskytla dítěti prostor pro dostatečné soustředění.

Absence obou prvků, času a vybavení, je zásadním limitujícím prvkem vzdělávání v domácím prostř̌edí.

\section{Absence pedagogických dovedností}

Rodiče často také reflektují, že nejsou plnohodnotnými učiteli. Poukazují na to, že nemají vědomosti a dovednosti, kterými disponují učitelé, ani jejich autoritu. Nevědí např́ḱlad, jak dítě motivovat či jak mu látku vysvětlit. V řadě př́padů si také uvědomují, že učivo neovládají a že je pro ně obtížné je z internetu a ostatních dostupných zdrojů nastudovat tak, aby ho byli schopni dítěti kvalitně předat. 


\section{Rodiče nedisponují didaktickými dovednostmi učitele}

Rodiče velice otevřeně přiznávají, že nejsou vystudovanými pedagogy. Jestliže byli rodiče vhozeni do role pedagoga či jeho pomocníka, postrádají základní pedagogické a didaktické kompetence potřebné pro efektivní výuku. Jak podotýká matka dítěte ve třetí trúdě ZŠ, nejedná se o porozumění složitým vědomostem, ale porozumění tomu, jak vyučovat: „Kdyby mi učitelé vysvèttili zpiisob, jakým běžnè dèti ve škole vyučnji a ke čemu jsou všechna zadáni, která nám posilaji, protože to jsou prevážnè cvičení, ale nedovedu z toho pochopit, k čemu to má smèrovat."Matka prvostupňového žáka poukazuje na problém vysvětlování látky $\mathrm{s}$ ohledem na řazení učiva $\mathrm{v}$ ročníkovém kurikulu celého předmětu či (viz Dvořák, 2009) s ohledem na školní vzdělávací program dané školy, který není s rodiči často komunikován školou. Aspekt jasného propojení právě probírané látky s dlouhodobějšími didaktickými cíli tak podle výpovědi rodiči komplikuje vzdělávání doma.

Kromě chybějících didaktických dovedností (jak vysvětlit látku dítěti poté, co si ji nastudovali) si dále stěžují, že nemají dostatečnou autoritu jako učitelé v očích dětí, což jim komplikuje vzdělávání doma. ${ }^{11}$ Rodiče si dále stěžovali, že neví, jak vést dítě k pravidelnosti, jak je chválit a motivovat k náročnějším úkolům. Důsledkem toho pak je, že děti pracují neochotně a vyžadují značnou míru pozornosti ze strany rodičů.

\section{Rodiče nedisponují dostatečnými vědomostmi}

Rodiče často uvádějí, že pro dostatečně funkční podporu svému dítěti musí často na internetu vyhledávat mnoho informací. Učitelé tyto informace zcela běžně ovládají, ale rodiče nikoliv. Rodiče často neumí dítěti vysvětlit zadání, nejsou schopni poskytnout oporu při řešení úlohy a nezhodnotí, zda jejich dítě úkol vypracovalo správně (proto také někteří rodiče volají po správných odpovědích od učitelů). Pro mnohé rodiče se pak vzdělávání stává zatěžující činností, a to nejenom v případě, když musí rodič pomáhat s učením cizího jazyka, který neovládá. Matka chlapce v šesté tř́ídě, který se učí pět hodin denně a z toho 90 \% s matkou, uvádí toto: „Jsem prèsvědčena, že nèco synovi vysvètlím lépe, máme dost času na konk rétníproblém, ale všeobecnè nejdu tak do bloubky, je to takové spiš všeobecné. Učitel mu dá obsáblejšr info, já jen to, co si pamatuju nebo nastuduju predem..."Slova z ukázky souzní s tím, co říkají mnozí další rodiče, kteří reflektují svoji nedostatečnou vybavenost vědomostmi. Klíčovým pro-

11 Štech (2003) upozorňuje na to, že v domácím vzdělávání může být pro rodiče obtížné skloubit roli matky či otce s rolí náročného učitele. Na problém spojení obou rolí $\mathrm{v}$ jedné osobě způsobené těsným vztahem $\mathrm{k}$ vlastnímu dítěti poukazovali i rodiče vzdělávající své děti doma v době uzavření škol. 
blémem není to, že by si rodiče nemohli dohledat definici cizího slova či ukázku složitějšího fyzikálního jevu, ale to, že nemohou dětem předat hlubší porozumění učiva $\mathrm{v}$ širších souvislostech.

Důsledkem toho může být stresující situace. Nebo také redukce kurikula, jak ji popisuje matka chlapce v sedmé třídě: „Učim se s ním sama a učm bo pouze to, co umim, tj. matematiku. "V kombinaci s nedostatkem času a vybavení je to další značně zatěžující prvek.

\section{Dítě není připravené na vzdělávání doma}

Posledním hlavním problémem, který rodiče popisují jako omezující pro vzdělávání doma, je dítě samo. Rodiče argumentují tím, že jejich dítě je líné, nemá disciplínu, neumí se učit samo, nesoustředí se a nedokáže si organizovat učivo. Kritickým př́lkladem jsou děti se specifickými poruchami učení. Matka dítěte v sedmé tř́ídě to vyslovuje jasně: „Syn je dysgrafike a dyslektike, samostudium neprĭpadáv úvahu. "K tomu přidává, že její syn pracuje přibližně sedm hodin denně nad úkoly a ona se účastní pomoci při $90 \%$ z nich. Abychom to pochopili správně, připomínka nesměřuje $\mathrm{k}$ tomu, aby bylo úkolů méně, ale aby byly vhodněji koncipovány s ohledem na SPU jejího syna. Tento problém je však popisován pouze malou skupinou rodičů a rozhodně se jedná o složitější téma, které náš výzkum nebyl schopen dostatečně komplexně zachytit.

\section{Řešeni vedouci ke zlepsèeni vądèlávání v domácím prostredí}

Z odpovědí rodičů je zřejmé, že výuka probíhá na školách velmi různě a že jednotlivé rodiny mají velmi různé potřeby. Rodiče navrhují mnoho dílčích podnětů a s ohledem na omezený prostor se budeme věnovat pouze dvěma z nich, které se objevují nejčastěji: požadavku na online výuku a požadavku na snížení počtu zadávaných úkolů.

\section{Online výuka}

Nejvíce rodičů volá po větší aktivitě školy. Přejí si, aby byli učitelé ve výuce v domácím prostředí více ,přítomni“. Touží po online výuce s učitelkou, př́padně výukových videích, a přejí si, aby i při tomto zpưsobu výuky byli učitelé schopni učivo více vysvětlit. Učitelé by také mohli být k dispozici pro konzultace, aby se na ně děti mohly obracet $\mathrm{v}$ prŕpadě nejasností.

Rodiče totiž upozorňují na to, že se místo vzdělávání jedná o samostudium, nebot' někteří učitelé pošlou pouze zadání ve stylu „Nastuduj si učivo že strany 65-78" a vysvětlování se musí ujmout rodič. Při takovéto podobě vzdělávání doma pak rodiče narážejí na to, že neumí pracovat s učebnicí, dokonce ji někteří nemají k dispozici a mají jen pracovní sešity, neznají správné řešení úkolů a nemohou zjistit, zda jejich dítě při učení postupuje správně, a neví, jak to zjistit. Matka žáka v deváté třídě, který se učí 5 hodin denně 
a ona mu z toho jednu hodinu pomáhá, to popisuje následovně: „Mnohem lépe by se mi darilo motivovat syna, kdybych mu mohla objasnit smysl a význam v̌̌eho, co je po nèm požadováno. Bobužel mnobdy jej nenalézám ani já. Jsem naprosto presuédčena, že vétšina mu nebude nikedy k uřitku. "Rodiče nejsou profesí pedagogové a pochopitelně si nemuseli osvojit odpovědi na otázku, kterou učitelům často kladou žáci, když se ptají, proč se to musí učit.

Online konzultaci by proto rodiče uvítali nejen pro své děti, ale i pro sebe. Řada rodičů volá po instruktáži ,jak dělat učitele“, která by jim pomohla roli učitelů lépe zvládat.

Jestliže rodiče přiznávají, že nedisponují didaktickými kompetencemi ani znalostmi, je tato reakce pochopitelným návrhem. Rodiče si představují, že by př́ online výuce škola převzala zpět mnohé úkoly, které delegovala na rodiče. Nemuseli by už vyhledávat výslovnost německých slovíček ani motivovat dítě skrze sladkou odměnu za brzké vypracování úkolu, ale otěže výuky by opět převzal učitel. Dokonce někteří uvádějí, že se př̀i delegovaném samostudiu o žádné učení nejedná, nebot’ žáci mají jen „testy, úkoly, referáty a jiné žrouty času, které se navic známkuji. Roz̧odně to [ditěe] nijak nerozvijil!", uvádí např́klad matka žáka sedmé tř́ídy, který se učí 7 hodin denně a ona s ním 3 hodiny denně.

Navrhované řešení odráží poměrně sofistikované pedagogické uvažování rodičů a jejich nově nabyté zkušenosti. S pomocí online výuky by zadané úkoly od učitele přestaly být jednosměrným procesem. Učitel by totiž měl nově možnost sledovat, jak žáci pracují (,učitel by dal dètem druhou šanci doplnit zmeškeaný úkol", „nemáme splnèné úkoly od začatku roku a dostáváme dalši"), lépe by dokázal dětem vysvětlit novou látku než samotní rodiče (,„k tomu je préci učitelem, aby je učil, ne zadával úkoly") a dokázal žáky skrze video lépe motivovat. Rodiče také předpokládají, že by to prospělo i k udržování vzájemných mezilidských vztahů mezi učitelem a jejich dítětem. A předpokládají, že by ostatní spolužáci mohli zásadně motivovat jejich dítě, pokud by se setkávali ve virtuálním prostředí.

\section{Méně úkolů}

Druhým řešením, po kterém volají především rodiče druhostupňových žáků, je zásadně omezit šíri a rozsah učiva (viz kap. Dvě skupiny rodičů: první a druhý stupeň). Rodiče uvádějí, že se zadané penzum úkolů nedá ,poctivě stihnout". Ve výuce v domácím prostředí by se zaměřili pouze na hlavní předměty: matematiku, češtinu a angličtinu, eliminovali by výchovy (zejména hudební výchovu) a vedlejší předměty, jako je dějepis a př́ŕrodopis. Rodiče často navrhují omezit novou látku a věnovat větší péči procvičování, protože jim podpora dětí při vysvětlování látky zabere mnohem více času a energie než jenom kontrola správnosti úkolu. Matka chlapce ve čtvrté tř́dě, který se učí v průměru 4 hodiny denně, to pojmenovává jasně: „Kdyby se učilo jen to 


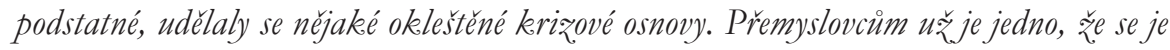
dèti nenauči ve 4. trúdè, ale počkaji do 6. [tř́dy] na dějepis. "Přemyslovci počkají, stejně jako výtvarná, hudební nebo tělesná výchova. Nyní je zapotřebí věnovat se „stěž́ejnim prédmétưm“ a ostatní předměty nechat do školy „na lepší časy“.

Spolu s omezením šíre učiva by mnoho rodičů uvítalo i nižší počet úkolů. Děti by neměly trávit tolik času prací do školy a mnohem méně by se na vzdělávání dítěte měl podílet rodič. Matka dívky ve čtvrté třídě, která se podílí na jejím vzdělávání zhruba hodinu denně, si to představuje takto: „Co nejvíce podkladü, které jen vytisknu a nechám dítè 15 minut pracovat o samotè a pak jen zkontroluji a dovysvétlim. "Mnozí rodiče by tedy chtěli nejen omezit množství zadané práce, ale chtěli by se také mnohem méně podílet na výuce svého dítěte. Důvody jsou zcela pragmatické: matka této dívky se stará ještě o další dvě děti. Je důležité podotknout, že tito rodiče zároveň často uvádějí, že jim práce zadaná učitelem připadá smysluplná.

Rodiče neporovnávají penzum zadaných úkolů jenom se svými časovými možnostmi v době pandemie, ale také s jiným významným ukazatelem množstvím práce, které mělo jejich dítě dříve zvládnout, když bylo nemocné. Matka žákyně sedmé třídy, která se učí sedm hodin denně, uvádí: „Pokud porovnám, co dítè muselo dopsat prí nemoci, se soućasnou dobou, nyni toho píse tak o 200 a vice procent vic!"Výpověd' matky dokumentuje, že i rodiče, kteří mohou pracovat z domu, nemusí projevovat nadšení z většího vytěžování svých dětí, než považují za smysluplné.

Rodiče by uvítali i méně úkolů, které sami rodiče hodnotí jako př́iliš triviální pro daný ročník (např. matka čturt’áka popisuje, že nerozumi tomu, proč si má syn opisovat do sešitu, že na jaře kvetou stromy), nebo jejich formu považují za neefektivní (napřr. ze syna se stává pisař, neustále má za úkol cosi opisovat do sešitu).

\section{Paradox digitální výuky:}

\section{Vice online výuky na počitači żnamená ménè času s počitačem}

Odpovědi prozrazují, že rodiče jsou v současné době nuceni více přemýšlet o žádoucí úloze informačních technologií ve vzdělávání jejich dětí. Rodiče by uvítali větší koordinaci učitelů, používání jedné platformy, dále volají po pravidelnosti, jednoduchosti a zdrženlivosti. Matka dívky v primě na víceletém gymnáziu, která se učí zhruba 6 hodin denně, přičemž ona sama u toho pomáhá tři hodiny denně, to shrnuje následovně: „Kdyby nechtěl každý profesor komunikovat jiným programem a zulástnim e-mailem a bakalárín. Každý jinak a každy chce jiné véci v jiném vyhotovení. Zabijim čas instalaci stahováni a pomáháním 12leté

12 Jedná se o online výukový systém Bakaláři (http://www.bakalari.cz), který je nejpoužívanější platformou v ČR. 
holce s obsluhou stahování, tisku, kopirováním, focením a odesiláním."S dobrým úmyslem zřejmě vedená snaha učitelů po dobrém technickém prostředí pro online výuku pro daný předmět se u rodičů někdy nesetkává s velkým pochopením. Proto volají po jednotné platformě a jednoduchém technickém řešení vzdělávání doma.

V tom, jak by mělo zadávání probíhat, nejsou však rodiče jednotní: někteři by uvítali zadávání úkolů ve větších celcích, aby si dítě mohlo práci rozvrhnout, a upuštění od klasifikace, jiní naopak volají po každodenních úkolech a pravidelné kontrole ze strany učitele.

$\mathrm{Na}$ čem se ale rodiče shodují, je to, aby se minimalizovala prímá práce dítěte s počítačem. Chtějí to jednak rodiče, kteří nedisponují dostatečným IT vybavením, stejně jako rodiče, kteří mají dostatek počítačủ, ale nemyslí si, že by dítě mělo trávit u počítače tolik hodin. Odporuje to jejich osobním přesvědčením. Děti by neměly trávit čas opisováním zadání z počítače, vyhledáváním informací na internetu či vypracováváním složitých prezentací.

Uvedli jsme však, že druhé navrhované řešení volá po větším zapojení učitelů do pravidelné online výuky. Není tu tedy rozpor? Pro rodiče nikoliv. I ti, kteří volají po online výuce, chtějí, aby se skrze toto řešení snížil čas dítěte a rodiče u počítače. Pokud by byl výklad učitele online, dítě by to pochopilo rychleji a lépe než s rodičem u počítače. Pokud by učitel vysvětloval důležité koncepty, nemusely by si je děti zdlouhavě vyhledávat na internetu.

\section{Spolupráce rodiny a školy}

Odpovědi na otevřené otázky prozrazují mnohé o tom, jak si rodiče představují spolupráci se školou, jaké požadavky kladou na učitele, čeho si na jejich práci cení a kde by naopak uvítali změny. Z řady výpovědí je zřejmé, že někteři rodiče začali práci a dovednosti učitelů v současné situaci více doceňovat. Zároveň je také vidět, že se výpovědi rodičů od sebe značně liší. To dobře vypovídá o tom, že se velmi liší práce jednotlivých škol a učitelů, ale rovněž o tom, že rodiče mají velmi různé požadavky, tedy je v zásadě nemožné zavděčit se všem.

To, že mnozí rodiče intenzivně reflektují vztah se školou a učiteli svých dětí, ukazuje časté používání mluvnického množného čísla $\mathrm{v}$ případech, kdy rodiče hovoří o svých dětech a škole. Kdyby nás učitelé nezatěžovali, kdybychom měli lepší pomůcky, hodil by se nám celodenní rozpis úkolů..., můžeme číst ve výpovědích rodičů. Ačkoliv např́klad ministerstvo školství používalo termín distanční vzdělávání, samotní rodiče spíše termín domácí vzdělávání, domácí učení či vzdělávání doma, nebot’ školní povinnosti nevnímali jako povinnosti jejich dítěte, ale zčásti i svoje vlastní.

A proto někteří rodiče překvapeně sdělovali, že je někteří učitelé z komunikace se svými žáky vynechali. Rodiče si stěžují na to, že na sebe učitelé neuvedli žádný telefonní kontakt, v některých př́padech ani e-mail, a učite- 
lé tak využívají jen jednosměrnou komunikaci a zadávají dětem úkoly. Rodiče nevolají jenom po tom, aby jejich děti dostávaly pravidelnou zpětnou vazbu, jak jsme viděli v požadavku na online výuku, ale byli by rádi, kdyby byli přizváni do komunikace o podobě a obsahu vzdělávání. V pomyslném trojúhelníku spolupráce rodiny a školy tak v těchto případech chybí jedna strana, komunikace učitelů s rodiči.

Matka dívky, která je v páté třídě a každý den se učí zhruba 5 hodin, uvádí vlastně velice jednoduché přání: „Aby děti dostávaly týdenni úkoly, tj. aby si ditě mohlo vybrat, co a kdy bude dělat, dosud neni možné se domluvit se školou, trvá si na dennim zadáváni úkolu a sledováni 3-4 rĩných informaíních kanáliu, videovýuka jazykü... naprosto nedostačujicí... "Citace zachycuje opakující se jev: rodiče jsou nespokojeni s formou nebo obsahem požadavků školy, ale učitelé na jejich požadavky nereagují nebo dokonce si rodiče nedovolí požadavky směrem k učiteli ani formulovat. Jen zřídka pak nalezneme komentáře rodičů, kteří říkají, že se s učiteli domluvili, aby se jejich dítě učilo méně, než pưvodně učitel chtěl, nebo se učilo jiným (individuálním) způsobem. Někteří rodiče nicméně uvádějí, že jim „dobrá komunikace s učitelkou“ pomáhá ze všeho nejvíc.

Rodiče si představují, že by škola a učitelé v ní měli být v těchto nelehkých časech empatičtí k situaci v rodině. Rodiče proto např́íklad uvádějí „...doma kromě dalš́ho školáka máme i predškoláka, kterému se také musime vénovat, aby z nèj nebyl debil. Na to se nebere absolutně zrètel."Matka žáka v šesté třídě, který se učí pět hodin denně, s nadsázkou upozorňuje na to, že by byla ráda, kdyby škola zohlednila při množství zadávání úkolů rodinnou situaci. Pokud však škola nenastavila komunikaci s rodiči, nemají učitelé šanci se dozvědět, že někteří žáci nemusí zadané úkoly zvládat nikoliv kvůli své lenosti, ale kvůli obtížné rodinné situaci.

$\mathrm{V}$ datech však najdeme i diametrálně odlišné příspěvky rodičů, kteří popisují, že škola jejich dětí si během krátké doby našla dobré způsoby, jak komunikovat nejen s dětmi, ale i s rodiči, a to se projevilo jak ve snížení nároků na děti, tak i ve větší spokojenosti rodičů se školou (nic dalšího nepotrebuji, škola funguje skevèle).

Symbiotickým prvkem odhalujícím absenci oboustranné komunikace mezi rodinou a školou je debata týkající se známkování. Rodiče často uvádějí, že jim připadá nepřijatelné, aby zodpovědnost za vzdělávání doma byla přenesena na děti a potažmo jejich rodiče, ale aby si na druhé straně učitelé ponechali možnost známkovat žáky za jejich výkon během učení doma. Matka dívky v osmé tř́ídě, která se učí 4 hodiny denně, to formuluje takto: „Aby učitelé prestali známkovat, kedyž nyni dèti neuči, aby více motivovali dèti, domlouvali se pri zadáváni látky tak, aby souvisela mezi predmèty..." Rodiče formulují logický požadavek, aby se na známkování svých dětí podíleli oni, nikoliv učitelé, kteří jsou spíše zadavateli než pedagogy. Je to nefér, říkají někteří rodiče, a zbytečně se tím vyvíjí na děti tlak k výkonu. 


\section{Větší autonomie na škole}

I když se jednalo o velice malou skupinu, v datovém korpusu bylo možné najít odpovědi rodičů volajících po větší autonomii na škole. Tuto malou skupinu lze rozdělit na dvě. První část tvoří rodiče, kteří by nechtěli online výuku, protože jim plně vyhovuje stávající forma samostudia. Jejich děti by měly od učitele dostávat jednoduché zadání, které by měly plnit, a učitel by neměl do vzdělávání doma nijak zasahovat, a to ani skrze obrazovku. S využitím typologie Štecha a Viktorové (2004) (viz výše) můžeme říci, že rodiče zastávají komplementární pojetí.

Druhou část tvoří rodiče zastávající nahrazující pojetí: nepřejí si, aby byli pouhými plniči úkolů, které zadávají učitelé, a kteří by zároveň chtěli, aby své děti mohli učit jak vlastním tempem, tak vlastním způsobem. „Kdybych mobla rídit tempo výnky svébo ditéte sama a nemusela posilat plnèni úkoli učitelce. Bez zásabi učitelky bych byla v menšim stresu a lépe by se nám doma učilo." Matka chlapce ve třetí tř́dě vysvětluje, že nechce od učitele méně úkolů, ale volá po vlastním tempu vypracovávání úkolů dítětem. Důvodem je snaha snížit stres vyvolávaný nutností plnit jednotné tempo nastavené pro všechny žáky, což mủže být dáno tím, že dítě má nějaké specifické poruchy učení, nebo jen nezájmem dítěte o plnění zadaných úkolů.

Kromě vlastního tempa pak větší autonomie znamená, aby mohli rodiče určovat, kterým úkolům se budou s dítětem věnovat více času a kterým méně. Matka třet’áka, který se učí 4 hodiny denně a ona s ním stráví 70 \% času, uvádí: „Kdybychom mobli jet vlastnim tempem, zamérit se na to, co mu nejde. Takble s vyplazeným jazykem stibneme jen to, co je zadáno, a nemìzeme více procvicüt dle potřeb ditěte. "Rodiče pomáhající dětem často uvádějí, že by si prúli, aby mohli mnohem pečlivěji a efektivněji podporovat učení svých dětí. Mohli by tak více probrat to, co dítěti nejde, nebo naopak přeskočit typy cvičení, které jsou z pohledu jejich a jejich dítěte jednoduché.

Jiní rodiče by v tomto volání po autonomii šli ještě dále: „Nechat volnou ruku na rodičich, ponze zadat, jaké jsou cile vądèlávání v daném ročníku. Kdyby ministerstvo a škola vydaly, co maji dèti umèt na konci školního roku... díté by se učilo ponze to, co potrebuje ke splnèni osnov, nikoliv neustálé opakováni a lpèni na nesmyslech..." Matka žákyně první trrídy, která se učí čtyři hodiny denně a z toho $80 \%$ času s matkou, vysvětluje, že by rodičům stačil cíl vzdělávání bez zevrubného popisu cesty k danému cíli. Rodiče by uvítali, kdyby děti dostávaly jasný cíl, ke kterému mají dojít, dobrovolné tipy a náměty, ale formu i obsah učení by doporučili nechat na dětech samých. Rodiče dětí jak z prvního, tak druhého stupně uvádějí, že taková výuka jejich děti více baví a ponechává prostor pro individualizaci jinak centrálně řízeného vzdělávání doma. Zároveň však uvádějí, že je tato podoba založena na komunikaci mezi učitelem, rodičem a dítětem. Nezamlčeným aspektem této formy vzdělávání je to, aby rodiče disponovali dostatečným množstvím času pro asistování svým dětem u uče- 
ní. Domnívají se, že by svobodnější výuka děti více bavila, více by se rozvíjely, pěstovala by se u nich zvídavost a připadala by jak rodičům, tak dětem smysluplnější.

\section{Závěr a diskuse}

Výsledky jasně ukazují, že mezi rodiči prvostupňových a druhostupňových dětí existují zřetelné rozdíly. Rodiče prvostupňových dětí pomáhají s úkoly svým dětem 40-60\% celkové doby, zatímco rodiče druhostupňových dětí $40 \%$ a méně času. Dále rodiče prvostupňových dětí vnímají zadané úkoly jako užitečnější (velmi užitečné a spíše užitečné) než rodiče žáků druhého stupně (spíše užitečné a spíše neužitečné). Jednoduše řečeno, rodiče prvostupňových dětí se s dětmi déle připravují a úkoly vnímají jako užitečnější než rodiče druhostupňových dětí. Výsledky odpovídají nižší angažovanosti rodičů druhostupňových žáků (Seginer, 2006).

Naším úkolem je odpovědět na zamlčenou otázku, čím může být tento

rozdíl způsoben. Zaprvé naše závěry potvrzují, že s postupujícími ročníky roste i náročnost kurikula (Hill \& Tyson, 2009), kvůli čemuž se rodiče druhostupňových dětí cítí méně kompetentní. Konkrétně si mnohem více stěžují na absenci vysvětlení úkolů učitelem (19,7 \% druhostupňových oproti $7,7 \%$ prvostupňových) a na absenci vlastních pedagogických dovedností a znalostí (15,4 \% druhostupňových oproti 12,5 \% prvostupňových). Zadruhé se domníváme, že na vině je i užitečnost zadaných úkolů, kterou rodiče druhostupňových dětí vnímají hủřre (spiše užitečné a spíše neužitečné) oproti rodičům žáků prvního stupně (velmi užitečné a spiše užitečné). Smysluplnost a užitečnost učiva se mnoha druhostupňovým rodičům jeví jako nízká i s ohledem na slabý rozvojový potenciál zadaných úkolů: nejasné zadání, nudné prosté opisování textu z počítače do sešitu či vyhledávání informací na internetu, nebo vypracovávání složitých prezentací v elektronické podobě.

Důsledkem toho může být rodiči již zmíněná snaha redukovat kurikulum, neschopnost rodičů vysvětlit učivo $\mathrm{v}$ širších souvislostech a v hlubší podobě a slabá motivace dětí dokončovat úkoly. Zmírnění této bariéry vidí jak rodiče druhostupňových dětí, tak rodiče prvostupňových dětí především v online výuce. $\mathrm{S}$ pomocí online výuky by zadané úkoly od učitele přestaly být jednosměrným procesem a učitelé by měli možnost sledovat proces učení žáků, dokázali by lépe vysvětlovat zadání či novou látku než rodiče a v neposlední ŕadě by byl učitel skrze online formu výuky lépe schopen motivovat žáky $\mathrm{k}$ dokončení úkolů. Jak jsme dále ukázali, od online výuky rodiče očekávají snížení času dítěte i rodiče u počítače. Pokud by byl totiž výklad učitele online, dítě by to pochopilo rychleji a lépe než s rodičem u počítače. 
Jestliže by učitel vysvětloval důležité koncepty, nemusely by si je děti zdlouhavě vyhledávat na internetu. Jen je nezbytné nezapomínat, že online výuka není pouhým přenesením klasické výuky na počítač, ale vyžaduje uplatnění zcela jiných pedagogických teorií, což zvyšuje nároky na samotné učitele (Zounek et al., 2016). Hledat tak spásu v zavedení jednotné platformy, která vyřeší všechny neduhy, je přinejmenším naivní.

Především rodiče druhostupňových dětí volají po jednotné elektronické platformě pro online výuku, což ale není triviální požadavek. Zavedení jednoho technického prostř́edí by však musela předcházet diskuse mezi učiteli na daném stupni, která by však zákonitě musela narážet na subjektivní přesvědčení učitelů o tom, který systém je ideální pro ně samotné a pro předmět, který vyučují. Domníváme se, že ač je tento požadavek rodičů jednoduše pochopitelný, ve své podstatě silně kontrastuje s autonomií učitele. Mnozí badatelé opakovaně varují před tím, že reformní tlak shora vnucující učitelům odlišnou profesní identitu, která není v souladu s jejich myšlením, může skončit nezdarem (viz Woods \& Jeffrey, 2002).

Je otázkou, zda by se učitelé nemuseli vzdát části své profesní autonomie ve prospěch jednotné školní platformy. Nicméně soudíme, že by učitelé pro rozhodnutí, který technický prostředek zvolit, potřebovali odbornou pomoc ze strany školy či ministerstva školství.

Zjištěné výsledky ukazují, že podobně jako se liší požadavky škol, liší se i pohled rodičů na bariéry a řešení vzdělávání doma. Škola se nemůže zavděčit všem rodičům, ale měla by s nimi komunikovat, můžeme číst v datech.

Co jsme se vlastně z ankety o vzdělávání doma dozvěděli o spolupráci učitelů a rodičů v době pandemie COVID-19? Školy byly na danou situaci pochopitelně zcela nepřipravené, ale repertoár jejich reakcí byl neuvěřitelně rozmanitý. Absence centrálního řízení na straně ministerstva školství a absence střední úrovně ŕízení na straně zřizovatele vedla $\mathrm{k}$ tomu, že školy, a především pak často sami učitelé, řešili situaci dočista odlišným způsobem. Podobně jako učitelé ani rodiče netvoří homogenní skupinu (Munn, 1993). Někteří rodiče si stěžovali na to, že jejich škola s nimi vůbec o vzdělávání nekomunikuje, učitelé nezadávali úkoly, avšak vedle toho jsme mohli číst výpovědi rodičů, kteří si spolupráci s učiteli svých dětí nemohli vynachválit, kteř́i byli denně online, zadávali užitečné a srozumitelné úkoly a s rodiči komunikovali. Nejen různé školy reagovaly různě, ale jak ukazují výpovědi rodičů druhostupňových žáků, různí učitelé z jedné stejné školy komunikovali s dětmi zcela odlišnou formou a zadávali úkoly s různou mírou náročnosti.

Dle výpovědí $\mathrm{v}$ anketě rodiče situaci zvládli dobře. $\mathrm{V}$ tomto smyslu výsledky výzkumu odpovídají zjištění výzkumu PAQ Research ze stejného období (Prokop et al., 2020) a šetření České školní inspekce (ČŠI, 2020). Vedle online výuky a snížení počtu úkolů by si však přáli lepší komunikaci školy a rodičů. Uzavření škol přineslo požadavek na rychlé a intenzivní za- 
pojení rodičů do vzdělávání svých dětí. Rodiče se museli o děti postarat jak po organizační a technické stránce, tak i po stránce pedagogické. Dřívější výtka mnoha teoretiků, že rodičovské zapojení je více rétorický konstrukt než realita, najednou přestala být adekvátní (Hornby \& Lafaele, 2011). Rodiče byli přinuceni vnějšími okolnostmi stát se angažovanými aktéry ve vzdělávání svých dětí.

Nálezy lze interpretovat i tímto zposobem: zatímco dříve rodiče očekávali, že učitelé jsou odborníky na vzdělávání a budou se ve škole dobře starat o své klienty (žáky) a informovat o tom rodiče (Rabušicová et al., 2004), nyní tomu bylo zcela naopak. Rodiče si s učiteli vyměnili zákaznickou roli. Od rodičů znenadání učitelé očekávali, že budou odborníky na vysvětlování látky, kontrolování správnosti úkolů a motivování a budou o splnění úkolů svými dětmi informovat učitele.

Za významné zjištění považujeme zprávu rodičů o tom, že nemohou dětem předat hlubší porozumění učiva v širších souvislostech, a naopak v tom vidí silně kompetentní učitele. Toto zjištění je nezbytné vnímat s ohledem na diskusi o domácím vzdělávání, které často stojí na tvrzení, že rodina je institucí př́znivou pro rozvoj dítěte (Štech, 2003). Rodiče odpovídající v naší anketě však nabízeli jiný pohled, když uváděli, že nemají dostatečnou autoritu jako učitelé v očích dětí, což jim komplikuje vzdělávání doma, a že nedisponují dostatečnou poznatkovou základnou, což vede k tomu, že se vysvětlování daného učiva vyhnou, nebo si uvědomují jeho povrchní objasnění dítěti. Považujeme to za důležité zjištění, protože rodiče ukazují, v čem spočívá role učitelů. Rodiči vykreslený učitel není chodící encyklopedie, ale učitel schopný propojit učivo do provázaných celků a vede žáky k tomu, aby si osvojovali učivo v širších souvislostech na makroúrovni školního roku či dokonce celého stupně (viz Dvořák, 2009). Podobně jako Štech (1994, 2003) vidí v učivu legitimizaci pedagogického vztahu mezi učitelem a žáky, obdobně vidí roli učitelů rodiče: učitelé by měli předat hlubší porozumění učiva v širších souvislostech žákům.

$\mathrm{V}$ médiích a na sociálních sítích se $\mathrm{v}$ době sběru dat opakovaně vedla diskuse o tom, zda by se výkony žáků při vzdělávání v domácím prostředí měly známkovat či nikoliv (učitelé např́iklad volali po zrušení známek Chrobák, 2020; Česká škola, 2020). V otevřených odpovědích naší ankety však rodiče kriticky poukázali na jiný aspekt debaty. Na rodiče byla delegována část pedagogických a didaktických povinností učitele, ale známkování si ponechali učitelé. Proč bychom neměli o známkách rozhodovat či alespoň spolurozhodovat, když se s dětmi doma poctivě učíme my, a ne učitelé? ptali se někteří rodiče.

Velkým překvapením je pro nás opakovaně se objevující volání rodičů po zúžení kurikula a funkcí školy. V odpovědích na otevřené otázky můžeme číst, že by podle rodičů bylo dobré omezit či úplně zrušit výuku v občanské 
výchově, dějepisu, hudební a výtvarné výchově. Někteří rodiče se dále podivovali nad tím, proč byly děti nuceny číst knihy, psát čtenářské deníky, a navrhovali, aby byly letní prázdniny zkráceny a děti „dohnaly učivo“ v jádrových předmětech. Jsou jádrové předměty tváří $\mathrm{v}$ tvář neočekávatelné epidemii důležitější pro budoucnost dětí než kurikulum občanské výchovy a dějepisu?

Překvapivě podobně málo jsme rovněž četli, že rodiče postrádají socializační funkci školy. Jen výjimečně rodiče popisovali, že by učitelé měli svoji pozornost zaměřit spíše na vztahy s dětmi či budování osobnostně-sociálních kompetencí. Matematickým rovnicím a gramatickým pravidlům je jedno, kdy si je žáci osvojí, ale platí totéž o „posvátném“ principu scholarizace (Štech, 2011), budování sociálního pouta mezi jednotlivými členy společenství?

Jaké ponaučení si z ankety může vzít samotná škola a její učitelé? Společně s rodiči považujeme zlepšení vzájemné komunikace za principiální požadavek. Škola by měla častěji a lépe komunikovat s rodiči o formě a obsahu výuky, což však předpokládá, aby škola rodiče ke komunikaci opakovaně vyzývala a aby škola vhodným zpo̊sobem nastavila komunikační kanály. Zahraniční výzkumy dokladují, že pokud jsou rodiče přesvědčeni, že škola si nepreje, aby se zapojovali, ve výsledku se prakticky nezapojují (Williams \& Sánchez, 2012). Na druhou stranu právě zvýšení frekvence komunikačních výměn mezi školou a rodinou je klíčovým prvkem pro zvýšení důvěry mezi oběma zapojenými aktéry (Adams \& Christenson, 2000). At’ už na rodiče pohlížíme jako na klienty či partnery školy, škola by kvůli rozvoji svých žáků měla usilovat o to, aby rodiče nezastávali rezignované pojetí bez zájmu o školu (Šed’ová, 2004; Štech \& Viktorová, 2004).

Tento požadavek však není ani jednoduchý, ani banální. Jak ukázaly výsledky ankety, na škole evidentně leží úkol vysvětlit rodičům žáků, že forma školního vzdělávání je zvolena správně, a obzvláště vyložit význam výchov pro celostní rozvoj dětí a jejich pozdější učení.

\section{Limity studie}

Prvním limitem studie je povaha souboru respondentů podmíněná skutečností, že se do ankety sami aktivně hlásili a že probíhala elektronicky. Ve výzkumném souboru byly zastoupeny vyšší měrou případy dětí, kde aspoň jeden z rodičů/vychovatelů dosáhl vysokoškolského vzdělání. Tyto případy tvořily v souboru $60 \%$, přičemž odhadovaný podíl v populaci dětí v povinném vzdělání je 40 \% (Brom et al., 2020a, 2020b). Na základě statistické analýzy našich dat jsme však záhy zjistili, že vzdělání rodičů mezi odpověd'mi př́liš nediferencovalo. Z této skutečnosti nemůžeme usuzovat, že vzdělání rodiče není důležitým faktorem z hlediska vzdělávání v domácím prostředí obecně, ale nediferencuje $\mathrm{v}$ našem souboru, kde byl pravděpodobně mnohem silnějším (a jednotícím) faktorem aktivní přístup ke vzdělávání dítěte demonstrovaný ochotou vyplnit elektronickou anketu. 
$\mathrm{V}$ důsledku metody sběru dat se nám nepodařilo také zachytit situaci rodin, které distanční vzdělávání jejich dětí nezajímá, nepodílejí se na něm nebo ve kterých vůbec žádné distanční vzdělávání neprobíhá. Velmi omezenou informaci jsme získali rovněž o vzdělávání dětí se speciálními vzdělávacími potřebami. Poučit se podrobněji o situaci těchto dvou skupin dětív době vzdělávání $\mathrm{v}$ domácím prostředí považujeme za velmi důležité.

Druhým limitem této studie jsou získaná data a jejich relevantnost pro kvalitativní obsahovou analýzu. $V$ této studii se ústředním datovým celkem analýzy staly odpovědi respondentů na dvě otevřené otázky. Otevřené otázky z dotazníků a anket bývají častým zdrojem dat pro kvalitativní analýzu, protože umožňují holistický pohled na zkoumaný problém (Albudaiwi, 2017). Při konstrukci obou otevřených otázek v naší anketě jsme se drželi následujících pravidel: otevřené otázky by měly být jednoduché, srozumitelné a bez návodného směřování, aby se mohl respondent zcela svobodně vyjádřit.

Odpovědi na první otázku jsme získali od 6476 respondentů v celkové délce 480000 znaků, tedy zhruba 256 normostran textu. Odpovědi na druhou otázku jsme získali od 7153 respondentů v celkové délce 507000 znaků, tedy zhruba 281 normostran textu. Všechna data však do kvalitativní analýzy nevstupovala, protože se často jednalo o krátké odpovědi, neúplná vyjádření nebo nesrozumitelné výroky. Domníváme se, že existují dobré důvody pro to, abychom tato data učinili objektem kvalitativní analýzy. At' už vezmeme Dismanovu definici, že kvalitativní př́stup ,je nenumerické šetřeni““ (Disman, 1998, s. 285), kdy pracujeme se slovy, nebo se obrátíme na způsob kvalitativní analýzy a interpretace, jehož podstatou je „hledání sémantických vztahů mezi nimi a spojování deskriptivních kategorií do logických celkư “ (Švařričck \& Šed’ová et al., 2007). Za nejdůležitější důvod však považujeme to, že povaha odpovědí nám umožnila porozumět uvažování rodičů, kteř́i byli schopni velice pečlivě zdůvodnit své jednání a argumenty podpořit svoje myšlenky. Jejich odpovědi proto považujeme za dostatečně kompetentní k tomu, abychom my výzkumníci porozuměli vnímání vzdělávání doma z pohledu perspektivy zkoumaných subjektů, rodičů (viz Denzin \& Lincoln, 2005; Fay, 2002). Zároveň však musíme podotknout, že nám v prvé řadě nešlo o objektivní popis reality (s ohledem na karanténní opatření to ani nebylo možné, např. nešlo provést zúčastněné pozorování vzdělávání doma), ale zachycení subjektivního pohledu rodičů na vzdělávání $\mathrm{v}$ době uzavřených škol (viz Morgan, 2007).

\section{Podíl autorů na textu}

Všichni autoři se podíleli na tvorbě ankety a sběru dat. Autorkou shlukové analýzy je Jana Straková a autorem kvalitativní části textu je Roman Švaříček. 


\section{Poděkování}

Děkujeme dvěma anonymním recenzentům, kteři přispěli ke zkvalitnění rukopisu. Poděkování si dále zaslouží studenti podílející se na zpracování dat, Fatima Adday, Radka Novotná, Ondřej Nešpor, Silvie Kř́žzová a Nicol Dostálová. V neposlední řadě děkujeme Renatě Týmové, vedoucí výzkumu a analýz v České televizi, za pomoc s distribucí ankety.

\section{Literatura}

Adams, K. S., \& Christenson, S. L. (2000). Trust and the family-school relationship examination of parent-teacher differences in elementary and secondary grades. Journal of School Psychology, 38(5), 477-497. https://doi.org/10.1016/S0022-4405(00)00048-0

Albudaiwi, D. (2017). Survey: Open-ended questions. In M. Allen (Ed.), The SAGE encyclopedia of communication research methods (1716-1717). SAGE.

Auerbach, S. (2007). From moral supporters to struggling advocates: reconceptualizing parent roles in education through the experience of working-class families of color. Urban Education, 42(3), 250-283. https://doi.org/10.1177/0042085907300433

Bastiani, J. (1993). Parents as partners. Genuine progress or empty rhetoric? In P. Munn (Ed.), Parents and schools: Customers, managers or partners? (s. 101-116). Routledge.

Bowen, G. A. (2009). Document analysis as a qualitative research method. Qualitative Research Journal, 9(2), 27-40.

Bracey, G. W. (1996). SES and involvement. Phi Delta Kappan, 78(2), 169-170.

Bridges, D. (1994). Parents: Customers or partners? In D. Bridges \& T. H. McLaughlin (Eds.), Education and the market (s. 65-79). The Falmer Press.

Brom, C., Greger, D., Hannemann, T., Lukavský, J., Straková, J., \& Švařríček, R. (2020a, duben 4). Rodiče v roli pedagogů. Předběžné výsledky dotazníkového šetření Vzdělávání doma. https://www.mff.cuni.cz/cs/verejnost/anketa-jaro-2020/setreni-vzdelavanidoma -ver200414.pdf

Brom, C., Lukavský, J., Greger, D., Hannemann, T., Straková, J., \& Švařríček, R. (2020b). Mandatory home education during the COVID-19 lockdown in the Czech Republic: A rapid survey of 1st-9th graders' parents. Frontiers in Education, 5. https://doi.org/10.3389/ feduc. 2020.00103

Carley, K. (1993). Coding choices for textual analysis: a comparison of content analysis and map analysis. In P. V. Marsden (Ed.), Sociological Methodology (s. 75-126). American Sociological Association.

Česká škola. (2020, duben 6). Ministr Plaga vydá vyhlášku, která omezí známkování domácí výnky. Vysvédíeni by mèlo být beže známek. Česká škola. http://www.ceskaskola.cz/2020/04/ministr-plaga-vyda-vyhlasku-ktera-omezi.html

ČŠI. (2020, duben 14). Vybraná zjištěni České školni inspekce k distančnimu vadělávání. Česká školní inspekce. https://www.csicr.cz/cz/Aktuality/Vybrana-zjisteni-Ceske-skolni-inspekce-k-distancni

Denzin, N. K., \& Lincoln, Y. S. (2005). SAGE Handbook of Qualitative Research. SAGE. 
Deslandes, R., \& Cloutier, R. (2002). Adolescents' perception of parental involvement in schooling. School Psychology International, 23(2), 220-232. https://doi.org/10.1177/0143034302023002919

Disman, M. (1998). Jak se vyrábí sociologická znalost. Príručka pro uživatele. Karolinum.

Dvořák, D. (2009). Řazení učiva v soudobých teoriích kurikula. Pedagogika, 59(2), 136-152.

Dvořák, P. (n. d.). Anketa. Sociologická encyklopedie. https://encyklopedie.soc.cas.cz/w/Anketa

Epstein, J. L. (1991). Effects on student achievement of teachers' practices of parent involvement. In S. B. Silvern (Ed.), Advances in reading/language research: A research annual, Vol. 5. Literacy through family, community, and school interaction (s. 261-276). JAI Press.

Epstein, J. L. (2001). School, family and community partnerships. Westview Press.

Fan, X., \& Chen, M. (2001). Parental involvement and students' academic achievement: a metaanalysis. Educational Psychology Review, 13(1), 1-22. https://doi.org/10.1023/A:1009048817385

Fan, W., Li, N., \& Sandoval, J. R. (2018). A reformulated model of barriers to parental involvement in education: comment on Hornby and Lafaele (2011). Educational Review, 70(1), 120-127. https://doi.org/10.1080/00131911.2018.1388614

Fantuzzo, J., McWayne, C., \& Perrty, M. A. (2004). Multiple dimensions of family involvement and their relations to behavioral and learning competencies for urban, low-income children. School Psychology Review, 33(4), 467-480.

Fay, B. (2002). Soǔáasná filosofie sociálních véd. Slon.

Galper, A., Wigfield, A., \& Seefeldt, C. (1997). Head Start parents' beliefs about their children's abilities, task values, and performances on different activities. Child Development, 68(5), 897-907.

Griffith, J. (1996). Relation of parental involvement, empowerment, and school traits to student academic performance. Journal of Educational Research, 90(1), 33-41.

Harris, A., \& Goodall, J. (2008). Do parents know they matter? Engaging all parents in learning. Educational Research, 50(3), 277-289.

Hegarty, S. (1993). Home-school relations: A perspective from special education. In P. Munn (Ed.), Parents and schools: Customers, managers or partners? (s. 117-130). Routledge.

Hill, N. E., \& Tyson, D. F. (2009). Parental involvement in middle school: a meta-analytic assessment of the strategies that promote achievement. Developmental Psychology, 45(3), $740-763$.

Hornby, G., \& Lafaele, R. (2011). Barriers to parental involvement in education: An explanatory model. Educational Review, 63(1), 37-52. https://doi.org/10.1080/00131911.2010.488049

Christenson, S. L., Rounds, T., \& Gorney, D. (1992). Family factors and student achievement: An avenue to increase students' success. School Psychology Quarterly, 7(3), 178-206. https:// doi.org/10.1037/h0088259

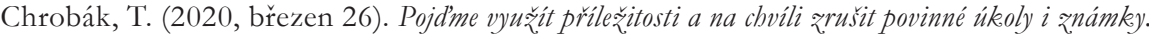
A pozorujme, co se stane. Rodiče vítáni. https://www.rodicevitani.cz/rodina-a-skola/domaci-priprava/tomas-chrobak-pojdme-vyuzit-prilezitosti-a-na-chvili-zrusit-povinne-ukoly-iznamky-a-pozorujme-co-se-stane/

Jeynes, W. H. (2005). A meta-analysis of the relation of parental involvement to urban elementary school student academic achievement. Urban Education, 40(3), 237-269. https:// doi.org/10.1177/0042085905274540

Jeynes, W. H. (2011). Parental involvement and academic success. Routledge.

Katrňák, T. (2004). Odsouženi ke manuálni práci: vždělanostní reprodukce v dèlnické rodinè. Sociologické nakladatelství. 
Kim, E. M., Sheridan, S. M., Kwon, K., \& Koziol, N. (2013). Parent beliefs and children's social-behavioral functioning: The mediating role of parent-teacher relationships. Journal of School Psychology, 51(2), 175-185. https://doi.org/10.1016/j.jsp.2013.01.003

Konopásek, Z. (2005). Co znamená interpretovat text? In M. Miovský, I. Čermák, \& V. Chrz (Eds.), Kvalitativni výzkeum ve védách o člověku IV. - vybrané aspekty teorie a praxe (s. 85-95). Univerzita Palackého. http://zdenek.konopasek.net/docs/Konopasek-Co-znamena-interpretovat-text.pdf

Kostelecká, Y. (2017). Home education experience in selected post-communist countries. In M. Gaither (Ed.), The Wiley bandbook of home education (s. 422-445). Wiley-Blackwell. https://doi.org/10.1002/9781118926895.ch17

Machovcová, K., Beláňová, A., Kostelecká, Y., \& McCabe, M. (2020). Rodičovské vnímání dětských potřeb a rozhodnutí vzdělávat doma. Studia paedagogica, 25(1), 33-50. https://doi. org/10.5817/SP2020-1-2

Mayring, P. (2000). Qualitative content analysis. Forum: Qualitative social research, 1(2). http:// dx.doi.org/10.17169/fqs-1.2.1089

Morgan, D. L. (2007). Paradigms lost and paradigms regained: Methodological implication of combining qualitative and quantitative methods. Journal of Mixed Methods Research, 1(1), 48-76. https://doi.org/10.1177/2345678906292462

Munn, P. (1993). Parents and schools: Customers, managers or partners? Routledge.

Plowden Report. (1967). Children and their primary schools. Report of the Central Advisory Council for Education in England. HMSO.

Prokop, D., Hrubá, L., \& Kunc, M. (2020, duben 6). Ekonomické problémy domácností a distanční vzdělávání. Report z. longitudinálního výzkumu Život bèhem pandemie. https://drive.google.com/ file/d/1xiYSzGcptexPnACF3CiEVqM13bfZwssm/view

Rabušicová, M., Šed’ová, K., Trnková, K., \& Čiháček, V. (2004). Škola a (versus) rodina. Masarykova univerzita.

Ramajzlová, Z. (2020, březen 25). Podnéty pro učitele a školy v nouzovém stavu s obledem na sociálné znevýhodnèné dèti. Člověk v tísni. https://www.clovekvtisni.cz/podnety-pro-ucitele-a-skolyv-nouzovem-stavu-s-ohledem-na-socialne-znevyhodnene-deti-6525gp

Rendl, M., \& Škloudová, A. (2004). Proměny „žákovstvi““v pražských školách. Sborník prací filozofické fakulty brnènské univerzity, 52(9), 17-35.

Roberts, C. W. (1989). Other than counting words: a linguistic approach to content analysis. Social Forces, 68(1), 147-77.

Seginer, R. (2006). Parents' educational involvement: A developmental ecological perspective. Parenting: Science and Practice, 6(1), 1-48. https://doi.org/10.1207/s15327922par0601_1

Singh, K., Bickley, P. G., Keith, T. Z., Keith, P. B., Trivette, P., \& Anderson, E. (1995). The effects of four components of parental involvement on eighth-grade student achievement: structural analysis of NELS-88 data. School Psychology Review, 24(2), 299-317.

Smetáčková, I. (2012). Škola jako téma rozhovorů mezi dětmi a rodiči. Studia paedagogica, 16(2), 9-26. https://doi.org/10.5817/SP2011-2-1

Šed’ová, K. (2004). Role rodičů ve vztahu ke škole: teoretické koncepty a empirická zjištění. In M. Rabušicová, K. Šed’ová, K. Trnková, \& V. Čiháček (Eds.), Škola a (versus) rodina (s. 33-51). Masarykova univerzita.

Šed’ová, K. (2009). Tiché partnerství: vztahy mezi rodiči a učitelkami na prvním stupni základní školy. Studia paedagogica, 14(1), 27-52. 
Štech, S. (1994). Co je to učitelství a lze se mu naučit? Pedagogika, 44(4), 310-320.

Štech, S. (2003). Škola, nebo domácí vzdělávání? Teoretická komplikace jedné praktické otázky. Pedagogika, 53(4), 418-436.

Štech, S. (2004). Angažovanost rodičů ve školní socializaci dětí. Pedagogika, 54(4), 374-388.

Štech, S., \& Viktorová, I. (2001). Vztahy rodiny a školy - hledání dialogu. In Z. Kolláriková \& B. Pupala (Eds.), Přeď̌kolní a primární pedagogika (s. 57-94). Portál.

Štech, S. (2011). Význam školy jako instituce. In O. Kaščák \& B. Pupala (Eds.), Škola - statický element v sociálnej dynamike (s. 15-24). Iura Edition.

Švaříček, R., \& Šed’ová, K., et al. (2007). Kvalitativní výzkum v pedagogických védách. Portál.

Turney, K., \& Kao, G. (2009). Barriers to school involvement: Are immigrant parents disadvantaged? Journal of Educational Research, 102(4), 257-271. https://doi.org/10.3200/ JOER.102.4.257-271

Williams, T. T., \& Sánchez, B. (2012). Parental involvement (and uninvolvement) at an inner-city high school. Urban Education, 47(3), 625-652. https://doi.org/10.1177/0042085912437794

Woods, P., \& Jeffrey, B. (2002). The reconstruction of primary teachers' identities. British Journal of Sociology of Education, 23(1), 89-106. https://doi.org/10.1080/01425690120102872

Zounek, J., Juhaňák, L., Staudková, H., \& Poláček, J. (2016). E-learning: učení (se) s digitálními technologiemi. Wolters Kluwer.

\section{Kontakt na autory}

Roman Švaříček

Ústav pedagogických věd, Filozofická fakulta, Masarykova univerzita, Brno

E-mail: svaricek@phil.muni.cz

Jana Straková

Pedagogická fakulta, Univerzita Karlova, Praha

E-mail: jana.strakova@pedf.cuni.cz

Cyril Brom

Matematicko-fyzikální fakulta, Univerzita Karlova, Praha

E-mail: brom@ksvi.mff.cuni.cz

David Greger

Pedagogická fakulta, Univerzita Karlova, Praha

E-mail: david.greger@pedf.cuni.cz

Tereza Hannemann

Matematicko-fyzikální fakulta, Univerzita Karlova, Praha

E-mail: hannemann@ksvi.mff.cuni.cz

Jiří Lukavský

Psychologický ústav, Akademie věd ČR, Praha

E-mail:lukavsky@praha.psu.cas.cz 


\section{Corresponding authors}

\section{Roman Švaříček}

Department of Educational Sciences, Faculty of Arts, Masaryk University, Brno

E-mail: svaricek@phil.muni.cz

Jana Straková

Faculty of Education, Charles University, Prague

E-mail: jana.strakova@pedf.cuni.cz

Cyril Brom

Faculty of Mathematics and Physics, Charles University, Prague

E-mail: brom@ksvi.mff.cuni.cz

David Greger

Faculty of Education, Charles University, Prague

E-mail: david.greger@pedf.cuni.cz

Tereza Hannemann

Faculty of Mathematics and Physics, Charles University, Prague

E-mail: hannemann@ksvi.mff.cuni.cz

Jiří Lukavský

Institute of Psychology, Czech Academy of Sciences, Prague

E-mail: jilukavsky@praha.psu.cas.cz 
SPOLUPRÁCE RODINY A ŠKOLY V DOBĚ UZAVŘENÝCH ZÁKLADNÍCH ŠKOL 41

Př́loha:

Charakteristiky respondentů zahrnutých do shlukové analýzy

$(\mathrm{N}=5482)$

\begin{tabular}{|c|c|c|}
\hline nejvyšší vzdělání v rodině & & $\%$ \\
\hline & nematuritní & 5,8 \\
\hline & SŠ & 30,0 \\
\hline & VŠ & 64,2 \\
\hline \multicolumn{3}{|c|}{ velikost obce, ve které rodina žije } \\
\hline & méně než 5000 & 31,9 \\
\hline & $5000-20000$ & 19,8 \\
\hline & $20000-100000$ & 16,3 \\
\hline & více než 100000 & 32,0 \\
\hline \multicolumn{3}{|l|}{ počet školních dětí v rodině } \\
\hline & jedno & 50,8 \\
\hline & dvě & 41,4 \\
\hline & tři & 6,9 \\
\hline & 4 a více & 0,8 \\
\hline \multicolumn{3}{|l|}{ ročník školní docházky } \\
\hline & 1 & 14,9 \\
\hline & 2 & 13,6 \\
\hline & 3 & 14,1 \\
\hline & 4 & 13,1 \\
\hline & 5 & 12,8 \\
\hline & 6 & 11,7 \\
\hline & 7 & 8,5 \\
\hline & 8 & 6,6 \\
\hline & 9 & 4,9 \\
\hline \multicolumn{3}{|c|}{ míra zvládání vzdělávání doma } \\
\hline & zvládáme & 16,5 \\
\hline & spíše zvládáme & 42,3 \\
\hline & tak napůl & 30,4 \\
\hline & spíše nezvládáme & 8,9 \\
\hline & nezvládáme & 1,9 \\
\hline \multicolumn{3}{|c|}{ dopad opatření spojených s karanténou } \\
\hline & jen malý & 4,4 \\
\hline & dá se to zvládnout & 70,8 \\
\hline & velký & 24,8 \\
\hline
\end{tabular}


